Thierry Lodé, Marie-Loup Lélias, Alban Lemasson, Catherine Blois-Heulin. Solitary versus group living lifestyles, social group composition and cooperation in otters. Mammal Research, 2020, $\langle 10.1007 /$ s13364-02000536-5〉. 〈hal-02950722〉

\title{
Authors' post-print
}

Editor's version available at the following:

https://doi.org/10.1007/s13364-020-00536-5

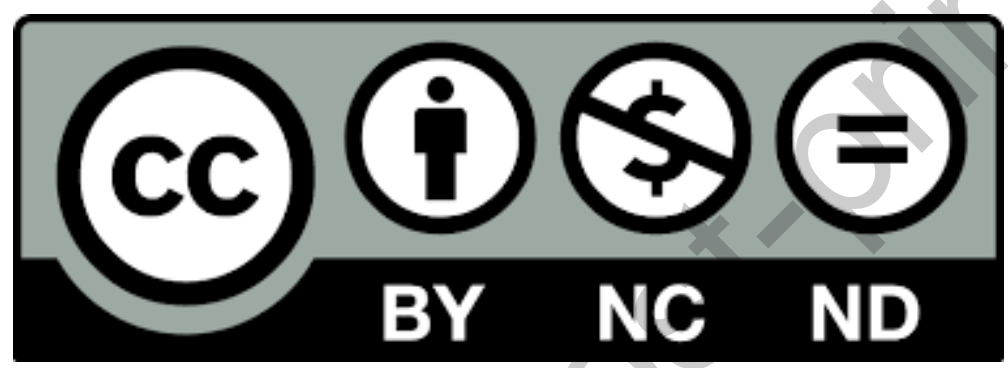




\section{Solitary versus group-living lifestyles, social}

2 group composition and cooperation in otters

3 Thierry LODÉ, UMR CNRS 6552 ETHOS, University of Rennes 1, 35042 Rennes,

$4 \quad$ France

$5 \quad$ thierry.lode@univ-rennes1.fr (corresponding author)

6 Marie-Loup LÉLIAS, LPPL, UPRES EA 4638, Université d'Angers, 49045 Angers

$7 \quad$ Cedex 01. France

8 Alban LEMASSON, Institut Universitaire de France \& UMR CNRS 6552 ETHOS,

$9 \quad$ University of Rennes 1, Station biologique de Paimpont, 35380, Paimpont, France

10 \& Catherine BLOIS-HEULIN, UMR CNRS 6552 ETHOS, University of Rennes 1, Station

11 biologique de Paimpont, 35380, Paimpont, France.

12

Small-clawed otters (Aonyx cinereus) (Photo Thierry Lodé). 


\section{ABSTRACT}

Increased reproduction success, enhanced foraging and reduced predation risk are usually regarded as major factors favouring the evolution of social behaviour. Here we formulate a series of hypotheses relating sexual, ecological and behavioural factors to evaluate their explanatory value for 13 extant otter species, estimating the extent to which each factor contributes to the sociality of each species. We also compare individual behaviours within some of the species. Four otter species are obligatory social; four are obligatory solitary; five present both types of social organization. Social organizations of otter species are not related to their phylogenetic relationships. However, many otter species exhibit intra-species patterns of flexible social lifestyles. Both solitary and social otters adjust their social patterns in response chiefly to food availability, but also to habitat features and competition.

Group living is more common when intraspecific competition is reduced or trophic resources replenish rapidly. Under these circumstances, group members often forage individually. When otters forage individually, they often switch prey type when they compete with other conspecifics. Social structures of otters fall into seven types: 1) family groups; 2) extended family groups, often with an alpha dominant pair; 3) highly social groups with helpers; 4) collective hunting groups; 5) solitary life-style; 6) unstable mixed-sex groups; and 7) single-sex bachelor groups. When an individual of a species with variable sociality adopts one type of sociality, this may be only temporary. Variations in social life are actually based on a series of events that induce individuals to make decisions taking ecological factors into account.

Although ontogenetic factors can influence delayed dispersal of otters, social factors rather than ecological factors could play an important role in the formation of groups, and cohesiveness and kinship appear to be secondary effects of reduced 
51 dispersal more than primary causes for living in a group. Appropriate adjustment of 52 group behaviour reduces the cost of sociality because individuals avoid social 53 interactions when benefits are low but gather together when group-living provides 54 real advantages. Although any one model is unlikely to explicate all facets of 55 sociality, evolution towards a social group results mainly from interactions within a 56 family.

57

58 Keywords cooperation, delayed dispersal, kin selection, parental care, reproductive 59 skew

60. 
62 Despite decades of research focusing on social and cooperative animals, many 63 questions concerning the evolution of group-living systems are still unresolved (Axelrod 1984, Pennisi 2005). How are group-living benefits to be understood in the context of Darwinian competition for survival? Simply, group living is theorized to evolve when

66

67

68 fitness benefits obtained by one individual within a group outweigh the costs of sharing key resources with conspecifics (Koenig et al. 1992; Cockburn 1998; Hatchwell and Komdeur 2000; Macdonald and Carr 1989; Bacon et al. 1991a, b; Johnson et al. 2000; Johnson et al. 2002b) and/or when there are strong ecological constraints on independent reproduction (Von Schantz 1984b; Lindström 1986; Hatchwell and Komdeur 2000). During the last few decades, this question has been debated within a diversity of theoretical frameworks (see West et al. 2007), but attention has focused especially on some highly social species.

Numerous advantages have been listed to explain why animals live in social groups. Increased reproduction success, enhanced foraging success and reduced predation risk are usually regarded as the major factors affecting the evolution of social behaviour (Hamilton 1964, Alexander 1974, Clutton-Brock 2002, Clutton-Brock et al. 2001). Nonetheless, these potential benefits can be broadly offset by costs linked to promiscuity resulting from living in groups, and natural selection should favour noncooperative selfish individuals (Creel 1997, West et al. 2002, Couzin 2006). Social animals face higher risks of disease and parasitism (Drewe 2009). Large groups are more susceptible to be detected by predators and put greater pressure on trophic resources leading to unequal delivery of food and increasing aggression among animals (Clutton-Brock et al. 2001, Krause and Ruxton 2002, Brewer 2008). Living in a social group could also lead to inbreeding or aggressive competition to find a mate and to raise young and infanticide between competing mothers. Finally, from an evolutionary 
point of view, why non-breeding individuals tolerate group-living and even help breeding conspecifics remains one of the most relevant questions (see Kokko and Johnstone 1999).

Although authors usually distinguish three aspects of social systems: social structure, care and mating systems, the need has emerged recently to differentiate between social structure, structural aspects of interactions within a society, and social organization, size and composition of the social unit (Prox and Farine, 2020). In fact, animal species exhibit a large diversity of social systems, social organisation and groupliving structure can vary within a zoological taxon (Reiczigel et al. 2008). For example, the social organizations of numerous species of otters vary considerably from solitary life (Lutra lutra, Kruuk and Moorhouse 1991, Lontra longicaudis, Rheingantz et al. 2017), to monogamous pairs (Lontra felina, Ostfeld et al. 1989), or extended family groups (Pteronura brasiliensis, Duplaix 1980, Ribas et al. 2016, Schmelz et al. 2017) and sometimes groups of males (Aonyx capensis, Arden-Clarke 1986; Lontra canadensis, Blundell et al. 2002a) (Table 1). Nevertheless, otters of the monophyletic subfamily Lutrinae (Bininda-Edmonds et al. 1999, Koepfli and Wayne 1998, Koepfli et al. 2008) reveal morphological similarities and present comparable amphibious habits and ecological requirements (Mason and Macdonald 1986, Kruuk 2006, Raha and Hussain 2016). Otters exhibit an elaborate range of societies and the combination of variable mating systems, social organizations and ecological and social characteristics provides a rare opportunity to analyse the importance of factors which could influence otters' social habits. The way social groups are categorized could help unravel factors arising from the environment or life histories (Prox and Farine 2020).

Here we formulated a series of hypotheses relating sexual, ecological and behavioural factors. For each hypothesis, we explain first its theoretical foundation, then 
112 we evaluate its explanatory value for 13 otter species, indicating the extent to which

113 each factor contributes to the sociality of each species.

114 Finally, by inspecting for parsimony among explanatory factors, we determine 115 whether otter sociality is the consequence of any single factor or a combination of 116 factors, across species. By focusing on the Lutrinae we hope to illustrate how 117 theoretical models could be applied to animals in order to discern future directions of the 118 social ecology paradigm.

\section{INTERSPECIFIC VARIATION OF SOCIALITY}

\section{Questioning advantages of kin group-living}

Sociality is theorized to evolve when the benefits of group living exceed the costs

(Axelrod 1984; Krause and Ruxton, 2002), but the role played by kinship in establishing social bonds needs to be evaluated.

Analyses of costs and benefits of sociality have often been made using Hamilton's rule on "Kin Selection" (Hamilton 1964). Kin selection favours the fitness of relatives at the expense of one's own survival and reproduction. Usually, "altruistic" behaviours are incorrectly called "cooperative" although they are not reciprocal and they reduce individual reproduction success (Wilson 1990). While cooperative interactions are supposed to be mutually beneficial, altruistic behaviours involve non-reproductive subordinates helping dominant individuals during the breeding period. The introduction 134 of the "kin selection" concept stimulated fruitful research on group-living animals, although relatedness among haplodiploid hymenoptera is higher than among other animals (Foster et al. 2006). For instance, genetic relatedness seems to predict the organization of social groups of dwarf mongooses Helogale parvula (Creel and Waser 
138

139

140

141

142

143

144

1994), kinkajous Poto flavus (Kays et al. 2000) and wild African elephants Loxodonta africana (Archie et al. 2006). Unsuccessful long-tailed tit (Aegithalos caudatus) breeders can act as helpers in the nests of close kin when the chance of successful independent reproduction is low (Hatchwell \& Sharp 2006). Male lion coalitions tend to consist of closely related individuals (Spong et al. 2002) and group-living females exhibit a high relatedness favouring their counter-action against infanticide (Mosser and Packer 2009).

Kin-mediated philopatry and cooperation benefits have been reported for numerous species. Assuming that the genes that promote altruistic behaviour favour increased feeding efficiency for instance suggests that this drives to produce a strong correlation between donor and recipient (Wilson 1990, Okasha 2002). Furthermore, limited or delayed dispersal increase the opportunities to interact with kin, and this could promote the evolution of cooperative breeding (Hamilton 1964). Nonetheless exploiting a resource by kin may also dramatically increase competition thus reducing all the benefits of cooperation.

Cooperative and altruistic kin-related behaviours could be maintained by other factors even in closely related groups and individuals presumed to be non-helpers could be cooperative (Komdeur 2006). Thus, the risk of predation considerably affects the pattern and time-budget of feeding. Sentinel behaviour in cooperative groups has been regarded as a form of altruistic anti-predator vigilance providing protection for the entire group (Hailman 1994). The alarm calls of Belding's ground squirrels (Spermophilus beldingi) indicate that sentinels alarm relatives and should be the result of kin selection (Sherman 1977). While sentinels take the risk of vocalizing, other individuals can increase time devoted to feeding (Manser 1999, 2001). Townsend et al. (2011) reported that meerkats are less vigilant when exposed to specific calls indicating that an individual has briefly scanned the surrounding environment for predators. Although the 
164 function of sentinels assures a cooperative vigilance (Wright et al., 2001b) it could 165 emerge from individually selfish antipredatory behaviour (Blumstein 1999). Whereas kin selection could underlie the evolution of some cooperatively breeding societies, this body of theory can hardly explain why some closely related species are not social while other species, exposed to similar ecological conditions, exhibit a complex social life. Thus, the absence of relatedness over the whole genome results in a strong selection for suppression of cooperative behaviour because the supposed altruistic gene would be in conflict with genes elsewhere in the genome (Grafen 2006, Helantera and Bargum 2007, West et al. 2007). Furthermore, when dispersal is reduced competition among kin can affect reproduction and can reduce, and even totally counteract, all kin-selected benefits for relatives (Griffin and West 2002, West et al. 2002, Gardner and West 2006). Consequently, it seems that sociological foundations prevail over purely kin factors.

It is often difficult to disentangle kin from non-kin mechanisms that promote group-living (Keller 1997). The North American river otter lives in large groups in marine environments (Rock et al. 1994; Larivière and Walton 1998) in habitats including inshore complexity and less reduction of foraging opportunities in winter than on inland lakes and rivers due to less freeze-up. Analysing the role of relatedness in these social habits, Blundell et al. (2004) rejected the hypothesis that social groups of otters were kin based. Group-living otters inhabiting coastal habitats included a group of individuals that were not related, as well as some that were closely related and both sexes exhibited a low probability of natal dispersal (Blundell et al. 2002b). Giant otters live in highly cooperative groups but Ribas et al. (2016) reasoned that direct benefits, such as alloparental care, and defence of high-quality home-ranges may have driven the development of sociability in this species. Small-clawed otter (Aonyx (Amblonyx) cinereus) groups are known to include unrelated juvenile adults (Foster-Turley 1992, 
190 Furuya 1976). Kin recognition mechanisms of mustelids do not differ clearly from

191 specific recognition of familiar but unrelated conspecifics (Lodé 2008, Hansen et al.

192 2009). Oriental small-clawed female otters discriminated between familiar and

193 unfamiliar adult males based on their sound and odour (Lemasson et al. 2013). Indeed,

194 relatedness among group members of numerous carnivores can be high, especially

195 when dispersal is restricted (Creel and Waser 1994, Girman et al. 1997, Gompper et al.

196 1997, Clutton-Brock 2002). Kin-structured populations can occur in solitary species

197 when their dispersal is restricted, as in cooperative species (Shorey et al. 2000, Lodé

198 2001, Foerster et al. 2006, Wagner et al. 2007), thus indicating that kin selection is not a

199 necessary condition for cooperation to emerge. Indeed, collective hunting by otters does

200 not require association with kin (Blundell et al. 2002b, Schmelz et al. 2017), resulting in

201 no selection pressure for kin-based groups. Therefore, although kinship undoubtedly

202 promotes social tolerance, it could be argued that the kinship observed in some highly

203 social animals could be a secondary effect of reduced dispersal and colonial living

204 rather than a primary cause for group living when their natal territories can support food

205 requirements.

206

207 Sociality and phylogeny

208 Based on the phylogenetic relatedness within the taxon Lutrinae, we would expect to 209 identify fairly similar social phenotypes. Lutrine otters form a monophyletic family which 210 diverged from other mustelids about 20-25 million years ago (Koepfli and Wayne 1998),

211 but variations of sociality among species appears to be unrelated to their taxonomic 212 positions (Kruuk 2006). Thus, the social organizations of otters seem not to be 213 associated with phylogenetic relationships, as measured through super-tree 214 constructions (Bininda-Edmonds et al. 1999, Koepfli et al. 2008) (Fig. 1). The social 215 structures, mating systems and behaviour of many otter species are not well known but 
216 both the largest (the giant otter) and the smallest species (the small-clawed otter) are 217 reported to develop strong social interactions (Kruuk 2006). Two species of the genus 218 Lontra remain strictly solitary, while two other species apparently can adopt a more social behaviour depending on the circumstances. Indeed, otters seem to exhibit very

220 variable social patterns: social, flexible and solitary.

While marine otters (Lontra feline) or spotted-necked otters (Lutra (Hydrictis) maculicollis) often exhibit solitary habits (Lejeune 1989, Angelici 2005), these species can live in small family groups in numerous occasions (Ostfeld et al. 1989, Kruuk \& Goudswaard 1990, Medina-Vogel et al. 2006). In contrast, both southern river otters (Lontra provocax) (Larivière 1999, Sepúlveda et al. 2007), hairy-nosed otters (Lutra sumatrana) (Sivasothi and Nor 1994, Nguyen et al. 2001; Nguyen 2005, Kanchanasakha 2007) and Neotropical river otters (Lontra longicaudis) (Helder and DeAndrade 1997, Kasper et al. 2008, Rheingantz et al. 2011, Rheingantz et al. 2017) are mainly solitary, whereas North American river otters (Lontra canadensis) (Melquist \& Hornocker 1983, Rock et al. 1994, Larivière \& Walton 1998, Blundell et al. 2004) and European otters (Lutra lutra) have both solitary and social habits (Mason \& Macdonald 1986, Kruuk \& Morhouse 1991). Smooth-coated otters (Lutrogale persipicillata) can live in small family groups (Foster-Turley 1992, Sivasothi \& Nor 1994, Hussain 1996, Khan et al. 2010). Congo clawless otters (Aonyx congicus) privilege solitary habits (Larivière 2001, Jacques et al. 2009), whereas African clawless otters (Aonyx capensis) (ArdenClarke 1986, Ostfeld et al. 1989, Creel \& Mcdonald 1995) and small-clawed otters (Aonyx (Amblonyx) cinereus), often have social habits (Furuya 1976, Foster-Turley 1992, Hussain et al. 2011). Finally, giant otters (Pteronura brasiliensis) (Duplaix 1980, Carter and Rosas 1997, Leuchtenberger and Mourão 2008) and sea otters (Enhydra lutris) (Garshelis et al. 1984, McShane et al. 1995) are highly social. 
Socially, otter species therefore have less in common with other species of the

242 same genus than they have with other less closely related phylogenetically otter species

243 (Kruuk 2006). This suggests that otters' social life style does not depend on genetic 244 relatedness.

\section{Group-living and dispersal}

247 We questioned whether social life style could depend on factors delaying dispersal of 248 juveniles. Limited dispersal can indeed engender a relatively high level of relatedness among populations. Kin-patterns could be a by-product of dispersal patterns as similar patterns are observed in solitary species. Koenig et al.'s (1992) “Delayed-Dispersal Threshold Model" proposed that delayed dispersal could be one of the most important processes of social life because it generates kin-structured groups without requiring any kin discrimination mechanism. This hypothesis thus clearly predicts that breeding dispersal will be lower in cooperative species than in non-cooperative species. territories? Habitat saturation is regarded as the main constraint inducing breeding 257 individuals to delay breeding but fails to explain the evolution of delayed dispersal 258 (Koenig et al. 1992). The "Habitat Saturation Hypothesis" has been tested through manipulation of populations of birds and fishes but results were variable (Komdeur 1992, Bergmüller et al. 2005, Stiver et al. 2006). Authors have demonstrated that the reproduction success of cooperative carrion crows Corvus corone (Canestrari et al. 262 2008) increases with group size but investigating the ecology of delayed dispersal 263 Baglione et al. (2005) observed that philopatry in the carrion crow occurred mainly in the 264 less competitive and less variable environments and that cooperative breeding and delayed dispersal appeared to be independent of the availability of suitable breeding 266 habitats for subordinates (Baglione et al. 2005). Dispersal distances varied strongly 
within a species revealing extremely flexible dispersal strategies (Le Galliard et al. 2012) and dispersal could be more environmental condition-dependent than expected (Bowler and Benton 2005). Thus, resource availability may drive group size.

Parental care has been argued to be a precondition for limited dispersal and therefore, should promote a mechanism similar to, or undistinguishable from, kin-group selection. However European badgers' parental care may be very limited after weaning, but their dispersal is limited as long as their habitat does not appear to be saturated. Examining the genetic structure and the mating system of Coquerel's dwarf lemur (Mirza coquerelI), Kappeler et al. (2002) discussed "hidden" effects of kinship in the dispersal systems of apparently 'solitary' animals. They found that apparent 'solitary' individuals are structured in matrilines. As a result, paternity was widely spread among males and mixed paternities existed. The philopatry of solitary carnivore raccoon (Procyon lotor) females also influences the genetic structure of the entire population (Ratnayeke et al. 2002). Similarly, male-biased dispersal and female philopatry basically favour the social organization of corvids (Williams and Rabenold 2005). Species exhibit wide dissimilarities in dispersal strategies with no clear tendencies between solitary or cooperative species (Clobert et al. 2001). Dispersal distances of mammals are proportional to the size of their home-range, considering body size independently (Bowman et al. 2002). Emigration governs group dynamics and, indeed, cooperation appears more extensive among individuals of the sex that are less likely to disperse, mostly females (Wrangham and Rubenstein 1986). Furthermore, although limited dispersal can favour cooperation, it can also generate competitive interactions, especially between mates. Limited and delayed dispersal seems therefore to be a process similar to kin selection because constraints on dispersal have entailed the development of kin-structured populations. 
Mustelids' dispersal is often male-biased (Lodé 2001, Blundell et al. 2002b,

293 Mcdonald et al. 2008) and this is generally regarded as promoting avoidance of 294 inbreeding (Pusey 1987, Perrin \& Mazalov 2000). Polygyny should favour philopatry of 295 the limiting sex and dispersal of the other (Greenwood 1980), increasing the operational sex-ratio bias (ratio of breeding adults), so that males do not have the opportunity to find mates. Living in aquatic ecosystems and often in linear water courses could constitute a severe constraint to dispersal, and patterns of dispersal of breeding subaquatic mustelids proceed according to the stepping-stone model (Gadgil 1971, Sjöåsen 1997) in which sub-population exchanges are favoured in contiguous zones (Lodé 2002, Bifolchi and Lodé 2005). Thus, European otters exhibit only limited dispersal movements (Kalz et al. 2006). A relatively high proportion of sea otters could however be long-distance dispersers (Krkosek et al. 2007).

The formation of male groups appears to be linked to reduced dispersal and to the philopatry of females in polygynous species in which habitat saturation might occur. Single-sex groups are observed in some species, leading to male bachelor social congregations (Pope 1990, Ruckstuhl and Neuhaus 2000). By forming coalitions, species regarded as solitary, such as cheetahs (Acinonyx jubatus) and slender mongooses (Herpestes sanguineus) are expected to forage more successfully and to have better access to females (Caro and Collins 1987, Waser et al. 1994). Genetic similarity among siblings facilitates male coalitions and cooperation (Packer et al. 1991, Waser et al. 1994, Kays et al. 2000, Möller et al. 2001, Spong et al. 2002). When members of these alliances are related, they can benefit indirectly when the alliance enhances their future reproduction success (Packer et al. 1991, Kays et al. 2000, Mitani et al. 2000). Sea otters (Garshelis et al. 1984, Pearson and Davies 2005), African clawless otters (Arden-Clarke 1986) and North American river otters (Blundell et al. 2002a) can form male bachelor congregations but they do not always hunt together and 
318 do not form any coalition for mates. This suggests that mechanisms other than kinship

319 are involved in the formation of groups of males (Griffin and West 2002).

SOCIOECOLOGICAL AND LIFE-HISTORY RELATED HYPOTHESES

\section{Ecological constraints}

324 Could the strong constraints of aquatic habitats also weigh on the emergence of the otters' social life? Although otters live in aquatic habitats and have relatively similar ecological requirements, the different species present a great diversity of social structures, including solitary habits and group-living. Similarly, the social structures and mating systems of dolphins vary although they live in marine habitats and while the killer whales (Orcinus orca) travel in extremely stable social groups, most dolphin species appear to have a more fluid social organization (Tyack 1986, Baird et al. 1992, Möller et

al. 2001). By contrast, and although mongooses are known to show greatly complex social organizations associating adult breeders and helpers, water mongooses (Atilax paludinosus) live a strict solitary life despite the use of aquatic habitats (Ray 1997). Thus, we reason that freshwater ecosystems do not impair the social life style of 335 animals.

However, might ecological requirements and habitats in which a population resides influence whether or not a species lives a social life? Predator avoidance and the monopolization of food resources are often the two ecological hypotheses preferred

339 to explain the formation of social groups (Alexander 1974, Wrangham and Rubenstein 340 1986, Bergmüller et al. 2005, Ylönen and Brown 2007). Obviously, living in social 341 groups facilitates cooperation for foraging and defence (Smith et al. 2012). Proposing 342 the "ecological constraints hypothesis" Smith et al. (2008) showed that cooperation 343 could increase individual benefits for trophic resources and defence. The scarcity of 
344 breeding sites has been evoked as a key factor determining cooperative breeding in 345 birds (Koenig et al. 1992, Cockburn 1998). Analysing natal philopatry and cooperative breeding of Siberian jays (Perisoreus infaustus) Kokko and Ekman (2002) realized that "ecological constraint" is a term too wide to yield useful predictive power.

Nevertheless, low availability of resources could affect cooperative strategies significantly. In his detailed review of the literature available at that time, Powell (1979) proposed that the social organizations of mustelids were fundamentally based on intrasexual territoriality, with male home-ranges overlapping those of females. Basically, dependent on food resources, this spatial organization seems to form a socio-ecological pattern that is very common in carnivores (Johnson et al. 2000). Dispersion of resource patterns could drive socio-spatial organization, allowing some species to congregate with variable social organization (Macdonald \& Newman 2018). All otter social systems are considered as variations on a theme of female territories overlapped by larger male territories (Kruuk 2006).

The "Resource Dispersion Hypothesis (RDH)" (Macdonald 1983, Carr and Macdonald 1986, Johnson et al. 2002, Macdonald and Sillero-Zubri 2004) argues that when resources are heterogeneously distributed, group living may be less costly, even without cooperative behaviour. This resource-based hypothesis proposes that patchy resources favour the overlap of conspecific home-ranges, leading to the promotion of social life. The main predictions are that i) home range size would be independent of group size, ii) home-range size would increase with dispersal of prey, iii) but group size would be affected by resource heterogeneity and iv) by resource patch richness. The social organisation of the British populations of European badgers (Meles meles) was found to be coherent with the HDR hypothesis (Carr and Macdonald 1986). However, Mbizah et al. (2019) investigating lion groups could not confirm some of the HDR predictions since the evaluations of resource heterogeneity and resource patch richness 
370 did not show any significant effects on the size of lion groups. The sizes of European

371 badgers' territories in Spain were shown to be related to their richness rather than to patch dispersion (Revilla and Palomares 2002). During the non-breeding season males of numerous mustelids can maintain their territories for the defence of offspring

374

375

376

380 (Schröpfer et al. 1997), but by marking home-ranges actively males can also defend future mating opportunities. Therefore, the resource dispersion model can describe some environmental constraints restricting or favouring group-living rather than those driving social life (Revilla 2003, Verdolin 2009).

Nevertheless, following RDH, could groups be formed because mixed resources dispersed in space and time are indefensible individually? Although most reports are based on local data from one particular habitat / density region, the flexibility of social systems suggests however a slightly more complex situation. Groenendijk et al. 2015 conclude that giant otter societies are probably shaped by the spatial dispersion of lakes and food abundance and dispersion within these rich patches, while North American river otters have clearly broken some expectations. Indeed, many individuals exhibit roaming excursions and mustelids often show a high level of intolerance even between males and females and territoriality can sometimes be absent (Erlinge and Sandell 1986, Lodé, 1996a). Otters are often found to exploit aquatic organisms patchily in river courses, seashores and lakes but both solitary and group-living otters exhibit a similar pattern of resource utilization (Brzezinski et al. 1993, Rowe-Rowe and Somers 1998, Rosas et al. 1999, Somers \& Nel 2003, Medina-Vogel et al. 2004, Parker et al. 2005, Medina-Vogel and Gonzales-Lagos 2008; Córdova et al. 2009, Cabral 2010, Rheingantz et al. 2011). In addition, North American river otters' home-range sizes decrease with sociality, thus challenging the first prediction of the RDH (Blundell et al. 2002a). Nonetheless, in order to validate these views, we would need more data concerning different populations of the same species. 


\section{Reciprocal altruism}

398 Cooperative breeding means that the quality of interactions among conspecifics is 399 privileged, often promoting the emergence of 'altruistic' behaviours. What behavioural 400 rules make it likely that social groups will be formed? Nepotism can lessen conflicts 401 between selfish interests but authors now commonly admit that helpers are less closely 402 related to breeders than previously suspected (Clutton-Brock 2002), so how could 403 unrelated helpers benefit from progeny care?

Trivers' (1971) Reciprocal Altruism Hypothesis emphasized that group-living and 405 cooperation could result from reciprocal interactions providing mutual benefits.

406

407

408

409

410

411

412

413

414

415

416

417

'Reciprocal altruism' allows that altruistic acts exist between unrelated individuals as well as between relatives. This requires that individuals interact often and are able to recognize individuals with whom they have interacted. West et al. (2007) suggested that the use of the term 'mutual benefit' would be more correct. In a reciprocal cooperation, individual cost of cooperation is offset by long-term benefits of being helped, and helpers must be able to identify cheaters (Sachs 2004, West et al. 2007). For instance, blood sharing regurgitation by vampire bats (Desmodus rotuntus) is interpreted as 'reciprocal altruistic' food sharing (Denaut and McFarlane 1995). The formation of male baboon (Papio anubis) coalitions has been understood as an example of 'reciprocal altruism' (Packer 1977). Similarly, green woodhoopoes (Phoeniculus purpureus) exhibit behaviours that appear to meet all the criteria of reciprocity between unrelated helpers (Ligon and Ligon, 1983). At least three otter species present cooperative foraging and food sharing behaviours that seem to respond to a sort of reciprocal altruism.

Numerous examples of pseudo-reciprocity promoting self-serving behaviour have been mentioned in the literature (West et al. 2002). Unlike sentinel behaviour, helpers are however characterized by the asymmetry of the interaction because 'altruistic' 
422 individuals contribute care to offspring at the expense of their own progeny. Reciprocal 423 cooperation could be encouraged by a high rate of mortality that leads to the evolution 424 of these mutually beneficial interactions. Such events should act as enforcement 425 426 427 428 429 430 because they influence both the cost and benefit of cooperating (West et al. 2007).

Numerous species of group-living otters present sentinel behaviour, and at least, three otter species include helpers, i.e. cooperative foraging, food sharing and collective defence against predators by unrelated adults, yearlings or juveniles. Cooperative helpers are observed in Giant otters (Duplaix 1980, Davenport 2010, Groenendjik et al. 2014, Schmelz et al. 2017) and in American river otters (Rock et al. 1994, Larivière \& Walton 1998, Blundell et al. 2002a). The average relatedness within groups of Giant otters was high, but the degree of relatedness could vary within groups that included unrelated individuals, contradicting the current social hypothesis of a parent brood model (Ribas et al. 2016). Although the social structure of small-clawed otters has not yet been studied in detail in the field this species is considered the most social (Johnson et al. 2000) and many authors report that a group shares a nest and behaves as a social unit, that individuals practice allogrooming and "interactive games", and that siblings can help raise offspring, the alpha pair being dominant (Furuya 1976, Pellis 1984, Foster-Turley 1992, Sivasothi and Nor 1994, Sivasothi 1996, Larivière 2003, Kruuk 2006; Prakash 2010, Hussain et al. 2011, Perdue et al. 2013).

To reproduce successfully, animals require territories with good trophic availability and have to find sexual partners. The pay-to-stay hypothesis argues that help at nest constitutes a kind of "rent" paid to a dominant for being allowed to live in the dominant's home-range. So, rather than attempt to breed with difficulty after a dangerous dispersal trip, it may be reasonable to remain for one more year within the family, delaying breeding opportunity, to acquire better survival probability and parental experience (Komdeur 1996, Kokko and Johnstone 1999). This acquisition of experience 
448 could be one of the indirect gains of cooperative breeding (Clutton-Brock 2002) and is 449 obtained by waiting for better dispersal opportunities, especially in unpredictable 450 environments, so that cooperative breeding could appear to be making 'the best of a 451 bad job' (Rubenstein and Lovette 2007). Nevertheless, such indirect benefits do not seem to play a crucial role for western bluebird (Sialia mexicana) helpers' fitness 453 (Dickinson 2004). Mechanisms rewarding helpers are assumed to be more common 454 and more effective for maintaining cooperative breeding than punishment (Snowdon and Cronin 2007). Conversely, direct enforcement mechanisms, such as harassment, may not result in complete repression of within-group competition.

Competition for resources among individuals can then defeat cooperative

\section{INTRASPECIFIC VARIATION IN SOCIALITY}

\section{Variations in reproductive opportunity}

As social groups incorporate adults, how could competition for mates influence social life? The avoidance of inbreeding amongst closely related within-group kin could drive suppression of reproduction and/or drive extra-group kleptogamy. Reproduction ability variation among group members is called 'reproductive skew'. Indeed, group-living often inhibits subordinates' breeding (Wasser and Barash 1983). Basically, non-breeding individuals endure an intrinsic conflict concerning reproduction as they receive complex social and physiological messages implying social dominance, harassment and glucocorticoid stress (Creel 2001, Mech and Boitani 2003, Goymann and Wingfield 2004, Bennett 2009, Rubinstein and Sheng-Feng 2009). Thus, dominant adults of 
different mongoose species manipulate subordinates to suppress all their reproduction opportunities (Creel et al. 1992, Cant 2000, Clutton-Brock et al. 2004). In fact, behavioural inhibition of subordinates' reproduction abilities could be one of the keys to carnivores' social life (Creel and McDonald 1995). While the 'Optimal Skew Model' of reproductive suppression assumes that dominant pairs monopolize reproduction preventing subordinates from breeding (Vehrencamp 1983, Reeve and Keller 1995), Cant (2000) argued that control by the alpha pairs is chiefly social and often remains incomplete, sometimes allowing subordinates to reproduce more or less successfully. However, different models of reproductive skew seem to be declinations of a general theory, rather than alternative paradigms (Johnstone 2000).

Reproductive skew and dominance are not well known for most of the otter species, but the social structure of many otter species could suggest such a characteristic. Small-clawed otters and North American river otters form monogamous pairs but several individuals, up to thirteen, including young and helpers can live together (Furuya 1976, Pellis 1984, Foster-Turley 1992, Rock et al. 1994, Sivasothi 1996, Blundell et al. 2002a, Prakash 2010, Hussain et al. 2011, Perdue et al. 2013). A group includes a dominant pair of male and female adults and the hierarchical organization of the group around this alpha pair suggests a possible influence of low reproduction conflict and parental manipulation, inhibiting subordinates' mating. Similarly, only the original giant otter parents, the alpha pair, generally breed during their lifetime and juveniles behave as helpers (Duplaix 1980, Davenport 2010; Groenendjik et al. 2014). Nevertheless, subordinates, and especially females, can sometimes breed in some populations of giant and small-clawed otters.

Competition for access to sexual partners is a fundamental component of sexual selection, and dominance interactions result in inhibition or suppression reproduction of group-living subordinates without requiring individuals to be closely related. 
500 Nevertheless, close relatedness could increase tolerance to manipulation, especially 501 since the individuals forming a group generally originate from the same family. Thus, 502 evolution towards social groups could result from interactions within family groups 503 implying dominance and harassment that suppress subordinates' reproduction 504 opportunities. The alpha pair of meerkats (Suricata suricatta) increases survival rates of 505 their progeny by harassing subordinates (Griffin et al. 2003, Young et al. 2006). 506 Although reproduction opportunities amongst individuals of different ranks often show 507 that dominant individuals accrue greater reproduction benefits than subordinates, 508 banded mongooses (Mungos mungo) have been found to exhibit low reproductive 509 skew, suggesting that the societies of some social species such as banded mongeese 510 could be relatively egalitarian (Luca and Ginsberg 2001). Similarly, dwarf mongoose 511 subordinates can reproduce sometimes (Keane et al.1994).

512

\section{Variations in social patterns}

514 Most studies dealing with ecological constraints concern different morphologically 515 dissimilar species and different ecological resources. By contrast, otters show similar 516 amphibious habits and exhibit comparable ecological requirements although specific 517 social structures vary greatly. Many otter species are known to fluctuate intra518 specifically from solitary lifestyle (often called 'solitary' species) to group-living 519 organizations whereas other species exhibit stable social traits (Fig. 2). 'Solitary' 520 however does not mean asocial. The term 'solitary' applied to a species is misleading 521 because it ignores both indirect social interactions and social phases, i.e. between sexual partners or mother-cubs relationships for instance and I proposed that it could be 523 replaced by the term 'individualistic' (Lodé et al. 2003), not in its pejorative sense, but 524 meaning independent lifestyle. European otter populations can exhibit solitary ways of 525 life as well as social habits in some parts of their range (Kruuk 2006, Quaglietta et al. 
2014). Indirect social interactions through olfactory marks give extensive information about conspecifics and the social organization of solitary species is mainly based on odours. Solitary species such as polecats Mustela putorius (Lodé 2008) or social smallclawed otters (Lemasson et al. 2013) are capable of olfactory recognition.

Variations of social patterns illustrate that the term 'social life' encompasses numerous situations which are sometimes called 'solitary', 'subsocial', 'familial', 'eusocial' or 'highly' social. Quantitative measures of social level were proposed to estimate, along a sociality scale from solitary to eusocial, the 'tendencies of individuals to live in groups' as a result of philopatry, to exhibit reproduction altruism and conspecific tolerance (Nonacs 2000, Reiczigel et al. 2008, Bang et al. 2009, Avilés and Harwood 2012). In fact, the current consensus concerning group-living animals hypothesizes a selection progressively leading towards more elaborate forms of sociality, presupposing a 'solitary' ancestral state (Creel \& McDonald 1995, Véron et al. 2004, Dalerum 2007, Schultz et al. 2011, Smith et al. 2012). Nonetheless, we can imagine a more flexible ancestral state so that some species' solitary habits may stem from ancestors exhibiting a flexible social organization (Dalerum 2007). Thus, although four American otter species are phylogenetically closely related, they exhibit very divergent social traits, neotropical river otters and southern river otters live solitary lives although they have only recently diverged from North American otters and marine otters that can live in small family and social groups. Species showing solitary habits are equally distributed across the three continents (two species in Africa, two species in America and two species in Eurasia), conversely four of the seven group-living otter species are found in America, only one in Africa and two in Eurasia, showing weak differences among continents.

For sociality to evolve, the benefits of living in a group must outweigh the costs. (Krause and Ruxton 2002). In fact, Silk (2007) argued that the difficulty to link the 
552 effects of behavioural interactions to fitness explains why sociality varies across species

553 and habitats. Following Emlen and Wrege (1994) and Emlen et al. (1995), social 554 behaviour can however be consider as a series of decisions made by an individual 555 during its lifetime. As a component of social strategy, each behavioural option can 556 influence an individual's fitness and staying within the familial group could therefore 557 represent the 'best of a bad job', promoting future cooperation. Subordinates could 558 obtain some benefits by staying as helpers. Thus, delayed dispersal would be the best 559 decision when numerous competitors or predators are present and prolong the benefits of parental care (Ekman et al. 2001, Kokko and Ekman 2002). Females may inherit the home-range of their mother whereas males could be obliged to delay their dispersal until they have the opportunity to find an available territory and a mate, because many

563 females stay in their parental territories. In return, groups can help prevent receptive 564 females from invading 'floater' individuals. Such anti-harassment behaviour is observed 565 in baboons (Lemasson et al. 2008). Finally, female sociality could allow the best access to patchy resources when faced with competing males. Thus, the social system of 567 female white-nosed coatis (Nasua narica) favours their foraging success whereas larger 568 males are able to compete for food without living in groups (Gompper 1996). Group569 living patterns of communally rearing rodents (Octodon degus) vary according to food 570 availability and predation (Ebensperger et al. 2012).

571 While striped mice (Rhabdomys pumilio) show solitary habits in grassland but in the 572 arid succulent karoo they live in social groups comprising multiple adults of both sexes 573 that share a nest and the same territory (Schradin and Pillay 2005). Similarly, intra574 specific variations of gorillas' social organization are influenced by ecological and social 575 factors (Yamagiwa et al. 2003). In addition, hyenas adjust their grouping patterns 576 following a fusion-fission dynamics in response to feeding competition; they are the 577 most gregarious during periods of abundant prey, but forage alone when cooperative 
578 hunting attracts numerous competitors (Smith et al. 2008). Opportunistically solitary

579 individuals may gather in temporary unstable mixed-sex groups. The composition and 580 the stability of these groups differ across habitats and groups tend to be open and ever-

581 changing. For instance, members of aggregations of giraffes (Giraffa camelopardalis) 582 usually change every few hours (Leuthold 1979, van der Jeugd and Prins 2000). We 583 inferred that group-living patterns vary with sexual, ecological and behavioural factors 584 as in a mechanism that integrates the characteristics of social systems with individual 585 behavioural strategies and ecological requirements.

\section{EVIDENCE FROM OTTER SPECIES}

588

589

590

591

592

593

594

595

596

\section{Group structure changes}

Social otters pairs mate for life. As the alpha pair is dominant, offspring of subsequent years frequently stay with their parents, forming extended families and the territories of different groups do not overlap. Indeed, the reasons why females remain in their family group differ from those of males. For instance, North American river otter males are more social than females and to cooperate for feeding so that Blundell et al. (2002a) concluded that cooperative foraging is a key factor influencing social organization of coastal river otters.

Different forms of social organisation can occur even within a species. Groupliving otter species present more intraspecific variations than solitary species. By confining ourselves to the concept of 'social species' to understand the evolutionary determinants of group-living life, we underestimate both the evolutionary significance of so-called 'solitary' species, i.e. species showing solitary habits (Lodé et al. 2003) and the importance of intraspecific variations and the behavioural plasticity of populations. 
603 Therefore, by focusing on the population level rather than only on the species level, 604 analysis of changes in social life can highlight new relevant factors.

The group structure of otters changes according to trophic resources and social interactions and group stability differs across different habitats. While Prox and Farine (2020) suspect that tolerance and stability are two central elements of mammalian social organization, it seems that one of these traits is not independent of the other and that stability is promoted by social tolerance. Social life of numerous species seems actually to be organized around the more or less extended family. Thus, although

611 kinkajous generally solitarily (Kays \& Gittleman 2001), adult males and females within a 612 group were unrelated while subadults and juveniles were their offspring, suggesting a 613 family structure (Kays et al. 2000).

Nonetheless, juveniles can only stay if the parental territory can provide sufficient resources to meet their needs. Actually, otters adjust their grouping patterns in response to food availability, to competition and to predators. It could be reasoned that group-living formations are driven by sexual, ecological and behavioural variations 618 reflecting individual decisions and life-history traits, and emphasizing the structural role 619 of social interactions, even for solitary species. Thus, the term 'social life' could be 620 thought to reflect a set of quite different situations (Fig. 3) where each step builds a 621 more or less temporary social organization: i.e. 1) family group, 2) extended family group, often with an alpha dominant pair but with no helpers 3) social group with helpers, 4) collective hunting group (cooperative activities), 5) solitary life-style 6) 624 unstable mixed-sex group ('individualistic' foraging) and 7) male social congregation. By 625 identifying the main facets of social organization (excluding eusociality), and reflecting 626 more or less dynamic structures according to individual decisions and ecological 627 conditions, this typology of group-living is relevant for numerous species, avoiding 628 imprecise definitions such as subsocial. 
During ontogeny, interactions that define the place of each individual in a group

631 are developed within their family group. Solitary habits differ from family group because 632 offspring stay in their family group until they reach sexual maturity, whereas offspring 633 have to leave their mother and disperse soon after weaning when living a solitary life. 634 Although animals forage solitarily, they can gather opportunistically in open mixed-sex 635 aggregations (unstable mixed-sex group) for some hours or some months in response 636 to predation pressure or to exploit temporary abundant resource. These unstable 637 groups are mainly composed of females and juveniles, sometimes a family group can 638 join an unstable group temporarily. Juveniles in a family group disperse when they 639 reach sexual maturity while extended family groups include several generations of 640 young. Males may be encouraged to stay within an extended family group when competition for trophic resources is quite restricted and when females do not disperse, since their chances to find a mate are then reduced, leading to an extended family group. Thus philopatry and delayed dispersal would result in sexual competition for

644 mates, involving dominance-subordinate interactions with possible suppression of 645 reproduction (alpha dominant pair). Subordinates can be driven to become helpers to 646 facilitate their maintenance within a group forming a highly social group with helpers, 647 generally dominated by an alpha pair, although they can have a relationship involving 648 varying degrees of conflict with dominants. Helpers have to participate in the rearing of 649 the progeny but may forage 'individualistically'.

\section{Collective hunting and prey switching}

652 Collective hunting by otters may occur, in the form of cooperative activities, according to 653 the size and mobility of available prey and could be affected by competition with other 654 predators. Indeed, forming a cooperative group appears an efficient strategy allowing 
animals to catch rapid prey, often grouped in schools, or prey relatively large in regard

656

657

658

659

660

661

662

663

664

665

666

667

668

669

670

671

672

673

674

675

676

677

678

679

680

to their size, or when competitive interactions with other predators appear unfavourable (Packer and Ruttan 1988). While cooperative breeding could be regarded as an 'altruistic' behaviour because helpers contribute care to offspring at the expense of their own reproduction, collective hunting characterizes a more selfish behaviour. Packer and Ruttan (1988) provide a simple but operational definition of cooperation as 'hunting in the presence of a companion'. Collective hunting can sometimes be interspecific as for instance coyotes and American badgers. In fact, although collective hunting reveals a form of cooperative activities based on long-term relationships (Smith et al. 2012), it can sometimes result in a certain asymmetry of interactions such an unequal sharing of food (Packer \& Ruttan 1988, Boesch 1994), the breeding pair typically monopolizing most of food (Mech and Boitani 2003). Boesch and Boesch (1989) recognized different levels of cooperation including coordination and collaboration in hunting behaviour. However, hunting cooperation does not appear to require many deliberate interactions as suggested by subsocial spiders (Wickler and Seibt 1993), so that there is no reason to claim that cooperative hunting reflects advanced cognitive abilities or complex social organizations, since similar strategies are generally used for different prey (Packer and Ruttan 1988, Mech and Boitani 2003).

Finally, individuals may disperse, foraging and using a den alone (solitary life-style), or can gather opportunistically in unstable mixed-sex aggregation (unstable mixed-sex group) including mainly females and juveniles, or form single-sex bachelor groups (male social congregations) depending on ecological resources and predators. Solitary mustelids seem to switch prey (Delibes and Adrian 1987, Weber 1990, Lodé 1996b, 1997, Clavero et al. 2003, 2006, Prigioni et al. 2006, Remonti et al. 2008, Pagacz and Witczuk 2010) when they compete with other predators. Depending on prey type and on exploited habitat, solitary habits are favoured by prey switching to alternative resources, 
whereas specialization in particular prey types could facilitate congregations (Lodé

682 2000, Blundell et al. 2002a). Being aquatic species, otters' capacities to switch prey are 683 limited, ranging from fish to arthropods. Giant otters and Asian small-clawed otters are 684 able to cooperate and coordinate their predatory activities (Schmelz et al. 2017). In fact, 685 feeding specializations and behavioural inertia against prey switching could be linked to 686 the fact that efficient exploitation of distinct prey requires animals to have radically 687 different sensory motor skills to survive. Furthermore, the existence of the unstable rafts 688 of sea otters and of male bachelor social congregations, at least of North American river 689 otters and African clawless otters, suggest that dispersal and competition for mates cannot preclude group-living patterns and cooperation.

\section{A series of individual decisions}

693

We propose that group-living is driven by a sequence of individual decisions following sexual, ecological and behavioural covariance (SEB model). Although this model does not discriminate very well among variables, it can also account for the fission-fusion dynamics common to many group-living species. Simple immediate decisions within a

697 family group govern complex social interactions prone to favour reproduction success in 698 the long term. Individuals engage in different optional alternatives in response to more or less proximal factors:

1) Soon after weaning, an animal can either disperse or stay:

I) if it disperses, a) it can live an solitary life, exploiting a food resource until depletion when resources are distributed in patches, or $b$ ) it can join opportunistically an unstable mixed-sex group or $c$ ) it can join a bachelor group when trophic resources replenish rapidly or when it feeds upon large prey, or $d$ ) it can join another group and mate later, dispersal thus avoids inbreeding depression. 
ii) if it stays and remains in its family group, a) it can forage solitarily when good resource availability reduces competition, or b) it can hunt collectively when prey are 708 gathered in schools or are too large to be caught alone, or c) a family group composed of a female and her cubs can join an unstable group temporarily.

2) After reaching sexual maturity or when the alpha pair breeds,

711 i) it can disperse as in the first option,

712 ii) or it can stay and engage more or less subordinate behaviour, and becomes a helper

713 if it is tolerated by the dominant (Fig. 4). Although no genetic tests have yet proven

714

715

716 extrapair paternity, it is likely that several adult individuals participate in reproduction, especially in species such as small-clawed otters, American river otters and giant otters, as otters and mink may be capable of superfetation (Yamagushi et al. 2004, Broekhuizen et al. 2007).

Habitat features and prey types affect the social organization of otters suggesting that social systems could be associated with particular niche variations. A major reason of group-living can be found in the fact that the trophic resource replenishes rapidly, thus favouring the formation of a group. This is principally the case when invertebrates constitute the main food source. For instance, sea otters feed preferentially upon clams, mussels, sea stars and urchins and lead a very social life. Giant otters opportunistically eat the most abundant species locally and cooperate for hunting big fish and alligators (Rosas et al. 1999). Cape clawless otters' diets include few fish but many crustaceans and molluscs, whereas more solitaries species such as neotropical otters prey on small fish, smooth otters chiefly prey on large fish and Eurasian otters feed mainly on small fish, crayfish and amphibians. As a crab-specialist (Foster-Turley 1992, Kruuk et al. 1994, Melish et al. 1996, Kanchanasakha 2007, Hon et al. 2010) small-clawed otters exhibit a high level of social interactions in highly social groups with helpers, but are very flexible according to their environment (Perinchery 2008, Hussain et al. 2011, 
732 Perinchery et al. 2011, Perdue et al. 2013). It seems that intraspecific competition is

733 considerably reduced because patches of prey cannot be exploited in a single feeding

734 although each group member forages solitarily. Hunting success for such small prey is

735 likely to be dependent on dexterity and locomotor performances. Smooth-coated otters

736 can learn socially how to exploit novel food resources and adopt a 'copy when young'

737 strategy (Ladds et al. 2017). All otters are very agile in water, but because their short

738 claws do not extend beyond their forepaws, small clawed otters have an excellent 739 sense of touch and coordination. Similarly, group-living African clawless otters lack

740 claws and have been observed to feed on crabs, frogs and crayfish thus reducing 741 intraspecific competition (Butler and Marshall 1996, Somers 2000, Parker et al. 2005).

742 Though this species sometimes lives solitarily, African clawless otters can form family 743 groups of up to ten individuals (Butler and Marshall 1996). Similarly, spotted-necked 744 otters do not hunt cooperatively but can live in small family groups in swamps and lakes 745 where this species catches invertebrates, crabs and small fish (Kruuk and Goudswaard 746 1990).

Although marine otters mainly exploit molluscs, crustacean and benthic fish along rocky coasts, this species' social behaviour is reduced to a family group, and sometimes exhibits solitary habits, probably because this species uses wave-exposed habitats, is very vulnerable to predators and depends strongly on available safe rocky shelters (Villegas et al. 2007, Medina-Vogel et al. 2007, Mangel et al. 2010, Valqui 2011). Smooth-coated otters form monogamous pairs and during the monsoon season their 753 basic family group consists of an adult female and offspring, they live in large rivers and 754 swamps but forage in shallow waters for slow fish, frogs, crabs, and insects (Helvoort et 755 al. 1996, Hussain 1996, Perrin and D'inzillo Carranza 2000, Anoop and Hussain 2004, Khan et al. 2010). Group-living giant otters' diet in the flooded rain forest includes chiefly 757 small cichlids (Duplaix 1980, Carter and Rosas 1997, Davenport 2008; Leuchtenberger 
758

759

760

761

762

763

764

765

766

767

768

769

770

771

772

773

774

775

776

777

778

779

780

781

782

783

and Mourão 2008, Davenport et al. 2010), revealing that solitary foraging could diminish feeding competition within highly social groups. Giant otters can prey cooperatively upon some large fish or fish schools, individuals surrounding prey when hunting collectively (Rosas et al. 1999).

River otters have broad habitat preferences but while European and North American river otters inhabiting rivers and streams generally exhibit solitary habits and opportunistic diets (Melquist and Hornocker 1983, Mason and Macdonald 1986, Newman and Griffin 1994, Kruuk and Moorhouse 1991, Kruuk 1995, Beja 1996; Durbin 1998, Ludwig et al. 2002, Bifolchi and Lodé 2005). European otters appear to be more social than previously thought (Quaglietta et al. 2014) and most otter species can present flexible social behaviours. Sociality is related to habitat features and acquisition of food so that both North American river otters and European otters exploiting rocky coasts and small benthic fish can live in groups (Kruuk and Moorhouse 1991, Shannon 1991, Rock et al. 1994, Reid et al. 1994, Larivière and Walton 1998, Blundell et al. 2002a, Blundell et al. 2004, Cote et al. 2008).

Although exploiting the same resource can increase competition dramatically, larger groups of North American river otters coincide with increased availability of schooling fish, because a large number of individuals surround schools in cooperative hunting (Blundell et al. 2004). Conversely Neotropical river otters, southern river otters, and Congo clawless otters have been observed to exhibit solitary habits when prey is dispersed in patches, exploiting linear wooded freshwater brooks, rivers and lakes (Helder and De Andrade 1997, Pardini 1998, Angelici et al. 2005, Kasper et al. 2004, Kasper et al. 2008, Sepulveda et al. 2009, Gomez et al. 2010, Rheingantz et al. 2011). Although this is probably the case for some other otter species, sea otters are known to form opportunistically bachelor congregations and mixed-sex unstable groups called pelagic raft, including from a dozen to as many as a thousand individuals mainly 
784

785

786

787

788

789

790

791

792

793

794

795

796

797

798

799

800

801

802

803

804

805

806

807

808

because they are exposed to marine predators (Garshelis et al. 1984). However reproductive adult males remain territorial and exclusive (Riedman and Estes 1990, Pearson and Davis 2005). Sea otters are clam-specialists but show individual dietary patterns transmitted along matrilines mediating prey specializations and intraspecific competition (Monson et al. 2000, Estes et al. 2003, Johnson et al. 2009, Laidre et al. 2009).

\section{CONCLUSION}

Despite decades of research dealing with group-living among species, we are far from understanding the evolution of the social life of animals, maybe because it is unlikely that any one model can explicate all facets of sociality.

Social factors rather than ecological factors may play an important role in the formation and cohesiveness of groups in otter species. There is however much evidence that ecological factors and other habitat constraints limit dispersal and promote group-living. Variations of social life style actually reveal a series of events which give rise to individual decisions in cascade related to ecological factors, otters adjusting social patterns to environmental variations. Simple immediate decisions govern complex social interactions driving group-living and favouring future reproduction success. Originating from mother-cub relationships, the flexible social lifestyles of otter species can reduce the cost of sociality because individuals can avoid social interactions when benefits are low whereas they can gather together when group-living provides more advantages.

\section{ACKNOWLEDGEMENTS}


We are grateful to Dr Mark Hauber and three anonymous referees for their constructive comments. Thanks are due to Dominique Le Jacques for illustrations and to Ann Cloarec for English corrections.

\section{REFERENCES}

Alexander RD (1974) The evolution of social behavior. Ann Rev Ecol Evol Syst 5: 325-383.

Axelrod R (1984) The Evolution of Cooperation. Basic Books, New York.

Angelici FM, Politano E, Bogudue AJ Luiseli L (2005) Distribution and habitat of otters. Aonyx capensis and Lutra maculicollis. in southern Nigeria. Ital J Zool 72: 223-227.

Anoop KR, Hussain SA (2004) Factors affecting habitat selection by smooth-coated otters. Lutra perspicillata. in Kerala, India. J Zool Lond 263: 417-423.

Archie EA, Moss CJ, Alberts SC (2006) The ties that bind, genetic relatedness predicts the fission and fusion of social groups in wild african elephants. Proc Roy Soc B Biol Sci 273: 513-522.

Arden-Clarke CHG (1986) Population Density, Home Ranges and Spatial Organization of the Cape Clawless Otter, Aonyx capensis, in a Marine Habitat. J Zool 209: 201-211.

Avilés L, Harwood G (2012) A Quantitative Index of Sociality and Its Application to Group-Living Spiders and Other Social Organisms. Ethology 118:1219-122.

Baglione V, Marcos JM, Canestrari D, Griesser M, Andreotti G, Bardini C, Bogliani G (2005) Does year-round territoriality rather than habitat saturation explain delayed natal dispersal and cooperative breeding in the carrion crow? J Anim Ecol 74: 842-851.

Baird RW, Abrams PA, Dill LM (1992) Possible indirect interactions between transient and resident killer whales. implications for the evolution of foraging specializations in the genus Orcinus. Oecologia 89: 125-132.

Bang A, Deshpande S, Sumana A, Gadagkar R (2009) Choosing an appropriate index to construct dominance hierarchies in animal societies. a comparison of three indices. Anim Behav 79: 631-636.

Beja PR (1996) Temporal and spatial patterns of rest-site use by four female otters Lutra lutra along the south-west coast of Portugal. J Zool Lond 239: 741-753.

Bennett NC (2009) Reproductive suppression in social Cryptomys damarensis colonies - a lifetime of socially-induced sterility in males and females. Rodentia, Bathyergidae. J Zool Lond 234: 25-39.

Bergmüller R, Heg D, Taborsky M (2005) Helpers in a cooperatively breeding cichlid stay and pay or disperse and breed, depending on ecological constraints. Proc R Soc Lond B Biol Sci 272: 325-331. 
Bifolchi A, Lodé T (2005) Efficiency of conservation shortcuts, a test with European otter as umbrella species for biodiversity preservation. Biol Conserv 126: 523-527.

Bininda-Edmonds ORP, Gittleman JL, Purvis A (1999) Building large trees by combining phylogenetic information, A complete phylogeny of the extant Carnivora Mammalia. Biol Rev 74:143-175.

Blumstein DT (1999) Enhanced. Selfish Sentinels. Science 284: 1633-1634.

Blundell GM, Ben-David M, Bowyer RT (2002a) Sociality in river otters, cooperative foraging or reproductive strategies? Behav Ecol 13: 134-141.

Blundell GM, Ben-David M, Groves P, Bowyer RT, Geffen E (2002b) Characteristics of sexbiased dispersal and gene flow in coastal river otters, implications for natural recolonization of extirpated populations. Mol Ecol 11: 289-303.

Blundell GM, Ben-David M, Groves P, Bowyer RT, Geffen E (2004) Kinship and sociality in coastal river otters; are they related? Behav Ecol 15: 705-714.

Boesch C (1994) Cooperative hunting in wild chimpanzees. Anim Behav 48: 653-667.

Boesch C, Boesch H (1989) Hunting behavior of wild chimpanzees in the Tai' National Park. Am J Phys Anthropol 78: 547-573.

Bowler DE, Benton TG (2005) Causes and consequences of animal dispersal strategies. relating individual behaviour to spatial dynamics. Biol Rev 80: 205-225.

Bowman J, Jaeger JAG, Fahrig, L (2002) Dispersal distance of mammals is proportional to home range size. Ecology 83: 2056-2061.

Brewer K (2008) Advantages and disadvantages of group living for animals. Orsett Psychological Services, Grays.

Broekhuizen S, Lammerstma DR, Müskens G (2007) Re-mating in otter (Lutra lutra). Lutra 2007 50 (2): 135-139

Sim Broekhuizen, Dennis R. Lammertsma \& Gerard J.D.M. Müskens

Brzezinski M, Jedrzejewski W, Jedrzejewska B (1993) Diet of otters Lutra lutra inhabiting small rivers in the Bialowieza National Park, eastern Poland. J Zool Lond 320: 495-501.

Butler JRA, Marshall BE (1996) Resource use within the crab-eating guild of the upper Kairezi River, Zimbabwe. J Trop Ecol 12: 475-490.

Cabral MMM, Zuanon J, De Mattos GE, Rosas FCW (2010) Feeding habits of giant otters Pteronura brasiliensis Carnivora Mustelidae in the Balbina hydroelectric reservoir Central Brazilian Amazon. Zoologia 27: 47-53.

Canestrari D, Marcos JM, Baglione V (2008) Reproductive success increases with group size in cooperative carrion crows, Corvus corone corone. Anim Behav 75: 403-416.

Cant MA (2000) Social control of reproduction in banded mongooses. Anim Behav 59: 147-158.

Caro TM, Collins DA (1987) Male cheetah social organization and territoriality. Ethology 74: 5264. 
882

883

884

885

886

887

888

889

890

891

892

893

894

895

896

897

898

899

900

901

902

903

904

905

906

907

908

909

910

911

912

913

914

915

916

917

918

919

Carr GM, Macdonald DW (1986) The sociality of solitary foragers, a model based on resource dispersion. Anim Behav 34: 540-1549.

Carter SK, Rosas FCW (1997) Biology and conservation of the giant otter, Pteronura brasiliensis. Mamm Rev 27: 1-26.

Clavero M, Prenda J, Delibes M (2003) Trophic diversity of the otter Lutra lutra L. in temperate and mediterranean freshwater habitats. J Biogeogr 30: 761-769.

Clavero M, Prenda J, Delibes, M (2006) Seasonal use of coastal resources by otters. Comparing sandy and rocky stretches. Est., Coast. Shelf Sc 66: 387-394.

Clobert J, Danchin E, Dhondt AA, Nichols JD (2001) Dispersal. Oxford University Press, Oxford.

Clutton-Brock TH (2002) Breeding together, kin selection and mutualism in cooperative vertebrates. Science 296: 69-72.

Clutton-Brock TH, Russell AF, Sharpe LL, Brotherton PNM, Mcllrath GM, White S, Cameron ED (2001) Effects of helpers on juvenile development and survival in meerkats. Science 293: 2446-2449.

Clutton-Brock TH, Russell AF, Sharpe LL (2004) Behaviour tactics of breeders in cooperative meerkats. Anim Behav 68: 1029-1040.

Cockburn A (1998) Evolution of helping behavior in cooperatively breeding birds. Ann Rev Ecol Syst 29: 141-177.

Córdova O, Rau JR, Suazo CG, Arriagada A (2009) Comparative study of the feeding ecology of the top predator Lontra felina. Molina, 1782. Carnivore, Mustelidae. in Chile. Revista de Biologia Marina y Oceanografia: 429-438.

Cote D, Stewart H, Gregory R, Reynolds J, Stenson G, Miller E (2008) Prey selection by marine coastal river otters. Lontra canadensis. in Newfoundland, Canada. J Mammal 89: 1001-1011. Couzin ID (2006) Behavioural ecology, social organization in fission-fusion societies. Curr Biol 16: R169R171.

Creel SR (1997) Cooperative hunting and group size, assumptions and currencies. Anim Behav 54: 1319-1324.

Creel SR (2001) Social dominance and stress hormones. TREE 16: 491-497.

Creel SR, Mcdonald DW (1995) Sociality, group size, and reproductive suppression among carnivores. Adv Stud Behav 24: 203-257.

Creel SR, Waser PM (1994) Inclusive fitness and reproductive strategies in dwarf mongooses. Behav Ecol 5: 339-348.

Creel SR, Creel NM, Wildt DE, Monfort SL (1992) Behavioural and endocrine mechanisms of reproductive suppression in Serengeti darf mongooses. Anim Behav 43: 231-245.

Dalerum F (2007) Phylogenetic reconstruction of carnivore social organizations. J Zool 273: 9097.

Davenport LC (2008) Behavior and ecology of the Giant otter. Pteronura brasiliensis in oxbow lakes of the Mnu biosphere reserve, Peru. Thesis, Univ. North Carolina. 
Davenport LC (2010) Aid to a declining matriarch in the Giant Otter Pteronura brasiliensis. PLoS One 5: e11385.

922

923

924

925

926

927

928

929

930

931

932

933

934

935

936

937

938

939

940

941

942

943

944

945

946

947

948

949

950

951

952

953

954

955

956

Delibes M, Adrian I (1987) Effects of Crayfish Introduction on Otter Lutra lutra Food in The Dofiana National Park, SW Spain. Biol Conserv 42: 153-159.

Denaut LK, McFarlane DA (1995) Reciprocal altruism between male vampire bats, Desmodus rotundus. Anim Behav 49: 855-856.

Dickinson JL (2004) A test of the importance of direct and indirect fitness benefits for helping decisions in western bluebirds. Behav Ecol 15: 233-238.

Drewe JA (2010) Who infects whom? Social networks and tuberculosis transmission in wild meerkats. Proc R Soc B 277: 633-642.

Duplaix N (1980) Observations on the ecology and behavior of the giant river otter Pteronura brasiliensis in Suriname. Rev Ecol Terre et Vie 34: 495-620.

Durbin LS (1998) Habitat selection by fiver otters Lutra lutra in river of northern Scotland. J Zool Lond 245: 85-92.

Ekman J, Eggers S, Griesser M, Tegelström H (2001) Queuing for preferred territories, delayed dispersal of Siberian jays. J Anim Ecol 70: 317-324.

Emlen ST, Wrege PH (1994) Gender, status and family fortunes in the white-fronted bee-eater. Nature 367: 129-132.

Emlen ST, Wrege PH, Demong NJ (1995) Making decisions in the family: an evolutionary perspective. Am Scient 83: 148-157.

Erlinge S, Sandell M (1986) Seasonal changes in the social organisation of male stoats, Mustela erminea, an effect of shifts between two decisive resources. Oikos 47: 57-62.

Ebensperger LS, Sobrero V, Quirici V, Rodrigo C, Tolhuysen L, Vargas F, Burger J, Quispe R, Villavicencio C, Vasquez R, Hayes L (2012) Ecological drivers of group living in two populations of the communally rearing rodent, Octodon degus. Behav Ecol Sociobiol 66: 261-274.

Estes JA, Riedman ML, Staedler MM, Tinkler MT, Lyon BE (2003) Individual variation in prey selection by sea otters, patterns, causes and implications. J Anim Ecol 72: 144-155.

Foerster K, Valcu M, Johnsen A, Kempenaers B (2006) A spatial genetic structure and effects of relatedness on mate choice in a wild bird population. Mol Ecol 15: 4555-4567.

Foster KR, Wenseleers T, Ratnieks FLW (2006) Kin selection is the key to altruism. TREE 21: 57-60.

Foster-Turley P (1992) Conservation ecology of sympatric Asian otters Aonyx cinerea and Lutra perspicillata. PhD Thesis, Univ of Florida.

Furuya Y (1976) Otters in Padas Bay, Sabah, Malaysia. J Mam Soc Japan 7: 39-43.

Gadgil M (1971) Dispersal, population consequences and evolution. Ecology 52: 253-260.

Gardner A, West SA (2004) Spite and the scale of competition. J Evol Biol 17: 1195-1203. 
Gardner A, West SA (2006) Demography, altruism and the benefits of budding. J Evol Biol 19: 1707-1716.

Garshelis DL, Johnson AM, Garshelis JA (1984) Social organization of sea otters in Prince William Sound, Alaska. Can J Zool 62: 2648-2658.

Girman DJ, Mills MGL, Geffen E, Wayne RK (1997) A molecular genetic analysis of social structure, dispersal, and interpack relationships of the African wild dog Lycaon pictus. Behav Ecol Sociobiol 40: 187-198.

Gomez JJ, Gozzi AC, Macdonald DW, Gallo E, Centron D, Cassini MH (2010) Interactions of exotic and native carnivores in an ecotone, the coast of the Beagle Channel, Argentina. Polar Biol 33: 1371-1378.

Gompper ME, Gittleman JL, Wayne RK (1997) Genetic relatedness, coalitions and social behaviour of white-nosed coatis, Nasua narica. Anim Behav 53: 781-797.

Gompper ME (1996) Sociality and asociality in white-nosed coatis Nasua narica foraging costs and benefits. Behav Ecol 7: 254-263.

Goymann W, Wingfield V (2004) Allostatic load, social status and stress hormones, the costs of social status matter. Anim Behav 67: 591-602.

Groenendijk, J., Hajek, F., Johnson, P. J., Macdonald, D. W., Calvimontes, J., Staib, E., \& Schenck, C. (2014). Demography of the giant otter (Pteronura brasiliensis) in Manu National Park, south-eastern Peru: implications for conservation. PloS one, 9(8), 106202. doi:10.1371/journal.pone.0106202

Grafen A (2006) Optimization of inclusive fitness. J Theor Biol 238: 541-563.

Greenwood PJ (1980) Mating systems, philopatry and dispersal in birds and mammals. Anim Behav 28: 1140-1162.

Griffin AS, West SA (2002) Kin selection, fact and fiction. TREE 17: 15-21.

Griffin AS, Pemberton JM, Brotherton PNM, Mcllrath G, Gaynor D, Kansky R, O'Riain J, Clutton-Brock TH (2003) A genetic analysis of breeding success in the cooperative meerkat Suricata suricatta. Behav Ecol 14: 472-480.

Groenendijk, J., Hajek, F., Schenck, C., Staib, E., Johnson, P. J., \& Macdonald, D. W. (2015). Effects of territory size on the reproductive success and social system of the giant otter, south-eastern Peru. Journal of Zoology, 296(3), 153-160

Hailman JP, Mcgowan KJ, Woolfenden GE (1994) Role of helpers in the sentinel behaviour of the Florida scrub jay Aphelocoma c coerulescens. Ethology 97: 119-140.

Hamilton WD (1964) The genetical evolution of social behavior I and II. J Theor Biol 7: 1-52.

Hansen H, McDonald DB, Groves P, Maier JAK, Ben-David M (2009) Social networks and the formation and maintenance of river otter groups. Ethology 115: 384-396.

Hatchwell BJ, Sharp SP (2006) Kin selection, constraints and the evolution of cooperative breeding in long-tailed tits. Adv Stud Behav 36: 355-395. 
Helantera H, Bargum K (2007) Pedigree relatedness, not greenbeard genes, explains eusociality. Oikos 116: 217-220.

Helder J, DeAndrade H (1997) Food and feeding habits of the neotropical river otter Lontra longicaudis (Carnivora, Mustelidae). Mammalia 61: 193-203.

Helvoort BE Van, Melisch R, Lubis IR, O'callaghan B (1996) Aspects of Preying Behaviour of Smooth-Coated Otters Lutrogale perspicillata from Southeast Asia. IUCN Otter Spec Group Bull 13: 3-7.

Hon N, Neak P, Khov V, Cheat V (2010) Food and habitat of Asian small-clawed otters in Northeastern Cambodia. IUCN Otter Spec Group Bull 27: 12 - 23.

Hussain SA (1996) Group-size, group structure and breeding in smooth-coated otter Lutra persipicillata Geoffroy Carnivora, Mustelidae. in National Chambal Sanctuary, India. Mammalia 60: 289-297.

Hussain SA, Gupta SK, de Silva PK (2011) Biology and Ecology of Asian Small-Clawed Otter Aonyx cinereus . Illiger, 1815, A Review. IUCN Otter Spec Group Bull 28: 63-75.

Jacques H, Véron G, Allary F, Aulagnier S (2009) The Congo clawless otter Aonyx congicus Mustelidae, Lutrinae, a review of its systematics, distribution and conservation status. Af Zool 44: 159-170.

Jeugd van der HP, Prins HHT (2000) Movements and group structure of giraffe (Giraffa camelopardalis) in Lake Manyara National Park, Tanzania. J Zool 251: 15-21.

Johnson CK, Tinke MT, Estes JA, Conrad PA, Staedler M, Miller MA., Jessup DA, Mazet JAK (2009) Prey choice and habitat use drive sea otter pathogen exposure in a resource-limited coastal system. PNAS 106: 2242-2247.

Johnson DDP, MacDonald DW, Dickman A (2000) An analysis and review of models of the sociobiology of the Mustelidae. Mam Rev 30: 171-196.

Johnson DDP, Kays R, Blackwell PG, Macdonald DW (2002) Does the resource dispersion hypothesis explain group living? TREE 17: 563-570.

Johnstone RA (2000) Models of reproductive skew, a review and synthesis. Ethology 106: 5-26. Kalz B, Jewgenow K, Fickel J (2006) Structure of an otter (Lutra lutra) population in Germany results of DNA and hormone analyses from faecal samples. Mamm Biol 71: 321-335.

Kanchanasakha BK (2007) Food Habitats of the Hairy-nosed otter Lutra sumatrana and the Small clawed otter Amblonyx cinerea in Pru Toa Daeng Peat Swamp Rorest, Southern Thailand. Xth International Otter Colloquium Hwacheon, South Korea.

Kappeler PM, Wimmer B, Zinner D, Tautz D (2002) The hidden matrilineal structure of a solitary lemur. implications for primate social evolution. Proc R Soc B 269: 1755-1763.

Kasper CB, Feldens MJ, Salvi J, Grillo HCZ (2004) Preliminary study by the ecology of Lontra longicaudis (Olfers) (Carnivora, Mustelidae) in Taquari Valley, South Brazil. Rev Bras Zool 21: 65-72. 
1031

1032

1033

1034

1035

1036

1037

1038

1039

1040

1041

1042

1043

1044

1045

1046

1047

1048

1049

1050

1051

1052

1053

1054

1055

1056

1057

1058

1059

1060

1061

1062

1063

1064

1065

1066

Kasper CB, Bastazini VAG, Salvi J, Hamilton CZG (2008) Trophic ecology and the use of shelters and latrines by the Neotropical otter Lontra longicaudis in the Taquari Valley, Southern Brazil Iheringia. Zoologia 98: 469-474.

Kays RW, Gittleman JL (2001). The social organization of the kinkajou Potos flavus (Procyonidae). Journal of Zoology. 253. 491 - 504.

Kays RW, Gittleman JL, Wayne RK (2000) Microsatellite analysis of kinkajou social organization. Mol Ecol 9: 743-751.

Keane B, Waser PM, Creel SR, Creel NM, Elliott LF, Minchella DJ (1994) Subordinate reproduction in dwarf mongooses. Anim Behav 47: 65-75.

Keller L (1997) Indiscriminate altruism, unduly nice parents and siblings. TREE 12: 99-103.

Khan WA, Qasim M, Ahmad E, Chaudhry AA, Bhaagat HB, Akhtar M (2010) Status of Smooth Coated Otter. Lutrogale perspicillata sindica. in Pakistan. Pak J Zool 42: 817-824.

Koenig WD, Pitelka FA, Carmen WJ, Mumme RL, Stanback MT (1992) The evolution of delayed dispersal in cooperative breeders. Q Rev Biol 67: 111-150.

Koepfli KP, Deere KA, Slater GJ, Begg C, Begg K, Grassman L, Lucherini M, Veron G, Wayne RK (2008) Multigene phylogeny of the Mustelidae, Resolving relationships, tempo and biogeographic history of a mammalian adaptive radiation. B M C Biol 6: 10.

Koepfli KP, Wayne RK (1998) Phylogenetic relationships of otters. Carnivora, Mustelidae. based on mitochondrial cytochrome B sequences. J Zool Lond 246: 401-416.

Kokko H, Ekman J (2002) Delayed dispersal as a route to breeding; territorial inheritance, 'safe havens' and ecological constraints. Am Nat 160: 468-484.

Kokko H, Johnstone RA (1999) Social queuing in animal societies. a dynamic model of reproductive skew. Proc R Soc Lond B Biol Sc 266: 571-578.

Komdeur J (1992) Importance of habitat saturation and territory quality for evolution of cooperative breeding in the seychelles warbler. Nature 358: 493-495.

Komdeur J (1996) Influence of helping and breeding experience on reproductive performance in the Seychelles warbler. A translocation experiment. Behav Ecol 7: 326-333.

Komdeur J (2006) Variation in individual investment strategies among social animals. Ethology 112: 729-747.

Krause J, Ruxton GD (2002) Living in groups. Oxford University Press, Oxford.

Krkosek M, Lauzon-Guay JS, Lewis MA (2007) Relating dispersal and range expansion of California sea otters. Theor Pop Biol 71: 401-407.

Kruuk H (1995) Wild Otters, predation and populations. Oxford University Press, Oxford.

Kruuk H (2006) Otters. ecology, behavior and conservation. Oxford University Press, Oxford.

Kruuk H, Moorehouse A (1991) The spatial organization of otters Lutra lutra in Shetland. J Zool 224: 41-57. 
Kruuk H, Kanchanasaka B, O'Sullivan S, Wanghongsa S (1994) Niche separation in 3 sympatric otters lutra-perspicillata, I-lutra Aonyx cinerea in Huai-Kha-Khaeng, Thailand. Biol Conserv 69: 115-120.

Kruuk H, Goudswaard PC (1990) Effects of changes in fish populations in Lake Victoria on the food of otters Lutra maculicollis Schinz and Aonyx capensis Lichtenstein. Afr J Zool 28: 322329.

Ladds Z, Hoppitt W, Boogert NJ (2017) Social learning in otters. R Soc open sci 30:4(8) 170489. http://dx.doi.org/10.1098/rsos.170489.

Laidre KL, Jameson RJ, Gurarie E, Jeffries SJ, Alllen H (2009) Spatial habitat use patterns of sea otters in coastal Washington. J Mamm 90: 906-917.

Larivière $S$ (1999) Lontra provocax. Mammal Sp 610: 1-4.

Larivière $S$ (2001) Aonyx congicus. Mammal Sp 650: 1-3.

Larivière S (2003) Amblonyx cinereus. Mammal Sp 720:1-5.

Larivière S, Walton LR (1998) Lontra canadensis. Mammal Sp 587: 1-8.

Le Galliard JF, Rémy A, Ims RA, Lambin X (2012) Patterns and processes of dispersal behaviour in arvicoline rodents. Mol Ecol 21: 505-523.

Lejeune A (1989) Ethologie des loutres Hydrictis maculicollis au lac Muhazi, Rwanda. Mammalia 53: 191-202.

Lemasson A, Palombit RA, Jubin R (2008) Friendships between males and lactating females in a free-ranging group of olive baboons (Papio hamadryas anubis). Evidence for playback experiments. Behav Ecol Sociobiol 62: 1027-1035.

Lemasson A, Mikus MA, Blois-Heulin C, Lodé T (2013) Social partner discrimination based on sounds and scents in Asian small-clawed otters (Aonyx cinereus). Naturwissenschaft 100: 275-279.

Leuchtenberger C, Mourão G (2008) Social organization and territoriality of giant otters. Carnivora, Mustelidae in a seasonally flooded savanna in Brazil. Sociobiology 52: 257-270.

Leuthold BM (1979) Social organization and behaviour of giraffe in Tsavo East National Park. Afr J Ecol 17: 19-34.

Ligon JD, Ligon SH (1983) Reciprocity in the green woodhoopoe Phoeniculus purpureu. Anim Behav 31: 480-489.

Lodé T (1996a) Conspecific tolerance and sexual segregation in the use of space and habitats in the European polecat. Acta Ther 41: 171-176.

Lodé T (1996b) Polecat predation on frogs and toads at breeding sites in western France. Ethol Ecol Evol 8: 115-124.

Lodé T. 1997 - Trophic status and feeding habits of the European Polecat Mustela putorius L., 1758. Mammal Review 27: 177-184

Lodé T (2000) Functional response and area-restricted search of a predator, seasonal exploitation of anurans by European polecat Mustela putorius. Austral Ecol 25: 223-231. 
1105

1106

1107

1108

1109

1110

1111

1112

1113

1114

1115

1116

1117

1118

1119

1120

1121

1122

1123

1124

1125

1126

1127

1128

1129

1130

1131

1132

1133

1134

1135

1136

1137

1138

1139

1140

1141

Lodé T (2001) Mating system and genetic variance in a polygynous mustelid, the European polecat. Genes Gen Systems 76: 221-227.

Lodé T (2002) Endangered species as indicator of freshwater quality, fractal diagnosis using fragmentation within European mink population. Archiv für Hydrobiol 155: 163-176.

Lodé T (2008) Kin recognition versus familiarity in a solitary mustelid, the European polecat Mustela putorius. C R Biol 331: 248-254.

Lodé T, Pereboom V, Berzins R (2003) Implications of an individualistic lifestyle for species conservation, lessons from jealous beasts. C R Biol 326: S30-S36.

Luca DW, Ginsberg JR (2001) Dominance, reproduction and survival in banded mongooses, towards an egalitarian social system? Anim Behav 61: 17-30.

Ludwig GX, Hokka V, Sulkava R, Ylönen H (2002) Otter Lutra lutra. predation on farmed and free-living salmonids in boreal freshwater habitats. Wildl Biol 8: 203-208.

Macdonald DW (1983) The ecology of carnivore social behavior. Nature 301: 379-384.

Macdonald DW, Sillero-Zubiri C (2004) The biology and conservation of wild canids. Oxford Univ Press, Oxford.

Macdonald D, Newman C (2018) Musteloid sociality: the grass-roots of society. In: Macdonald D, Newman C, Lauren AH (eds) Biology and conservation of musteloid, pp. 167-188.

MacShane LJ, Estes JA, Riedman ML, Staedler MM (1995) Repertoire, structure and individual variation of vocalizations in the sea otter. J Mam 76: 414-427.

Mangel JC, Whitty T, Medina Vogel G, Alfaro Shigueto J, Caceres C, Godley BJ (2010)

Latitudinal variation in diet and patterns of human interaction in the marine otter. Mar Mamm Sc 27: 14-25.

Manser MB (1999) Response of foraging group members to sentinel calls in suricates, Suricata suricatta. Proc R Soc. B 266: 1013-1019.

Manser MB (2001) The acoustic structure of suricates' alarm calls varies with predator type and the level of response urgency. Proc R Soc B 268: 2315-2324.

Mason CF, Macdonald SM (1986) Otters - ecology and conservation. Cambridge Univ. Press, Cambridge.

Mbizah MM, Valeix M, Macdonald DW \& Loveridge AJ (2019). Applying the resource dispersion hypothesis to a fission-fusion society: A case study of the African lion (Panthera leo). Ecol Evol. 9(16): 9111-9119.

Mech DL, Boitani L (2003) Wolves, behavior, ecology and conservation. Univ. Chicago Press, Chicago.

Medina-Vogel G, Gonzalez-Lagos C (2008) Habitat use and diet of endangered southern river otter Lontra provocax in a predominantly palustrine wetland in Chile. Wild Biol 14:211-220.

Medina-Vogel G, Bartheld JL, Pacheco RA, Delgado R (2006) Population assessment and habitat use of marine otter Lontra felina in southern Chile. Wildl Biol 12: 191-199. 
1142

1143

1144

1145

1146

1147

1148

1149

1150

1151

1152

1153

1154

1155

1156

1157

1158

1159

1160

1161

1162

1163

1164

1165

1166

1167

1168

1169

1170

1171

1172

1173

1174

1175

1176

1177

1178

Medina-Vogel G, Boher F, Flores G, Santibanez A, Soto-Azat C (2007) Spacing behavior of marine otters. Lontra felina. in relation to land refuges and fishery wastes in Central Chile. $J$ Mammal 88: 487-494.

Medina-Vogel G, Delgado C, Alvarez RE (2004) Feeding ecology of the marine otter Lutra felina in a rocky seashore of the south of Chile. Mar Mamm Sci 20: 134-144.

Melquist WE, Hornocker MG (1983) Ecology of river otters in west central Idaho. Wildl Monogr 83: 1-60.

Mitani JC, Merriwether DA, Zhang C (2000) Male affiliation, cooperation and kinship in wild chimpanzees. Anim Behav 59: 885-893.

Möller LM, Beheregaray LB, Harcourt RG, Krutzen M (2001) Alliance membership and kinship in wild male bottlenose dolphins (Tursiops aduncus) of southeastern Australia. Proc R Soc B 268: 1941-1947.

Monson DH, Estes JA, Bodkin JL, Siniff DB (2000) Life history plasticity and population regulation in sea otters. Oikos 90: 457-468.

Mosser A, Packer C (2009) Group territoriality and the benefits of sociality in the African lion, Panthera leo. Anim Behav 78: 359-370.

Newman DC, Griffin CR (1994) Wetland use by river otters in Massachusetts. J Wildl Manag 58: 18-23.

Nguyen XD (2005) Current status of otters Mammalia Lutrinae in Viet Nam with conservation implications. Tiger Paper 33: 8-14.

Nguyen XD, Pham TA, Le HT (2001) New Information about the Hairy-Nosed Otter Lutra sumatrana in Vietnam. IUCN Otter Sp Group Bull 18: 64-75.

Nonacs $P$ (2000) Measuring and using skew in the study of social behavior and evolution. Am Nat 6: 577-589.

Okasha S (2002) Genetic relatedness and the evolution of altruism. Phil Science 69: 138-149.

Ostfeld R, Ebensperger L, Klosterman L, Castilla J (1989) Foraging, activity budget, and social behavior of the South American marine otter Lutra feline. Nat Geog Res 5: 422-438.

Packer C (1977) Reciprocal altruism in Papio Anubis. Nature 265: 441-443.

Packer C, Ruttan L (1988) The evolution of cooperative hunting. Am Nat 132: 159-198.

Packer C, Gilbert DA, Pusey AE, O'Brien SJ (1991) A molecular genetic analysis of kinship and cooperation in African lions. Nature 351: 562-565.

Pagacz S, Witczuk J (2010) Intensive exploitation of amphibians by Eurasian otter Lutra lutra in the Wolosaty stream, southern Poland. Ann Zool Fenn 47: 403-410.

Parker DM, Burchell RK, Bernard RTF (2005) The diet of Cape clawless otters at two sites along the Bloukrans River, Eastern Cape Province, South Africa. Af Zool 40: 330-334.

Pardini R (1998) Feeding Ecology of the Neotropical River Otter Lontra longicaudis in an Atlantic Forest Stream, south-eastern Brazil. J Zool 245: 385-391. 
1179

1180

1181

1182

1183

1184

1185

1186

1187

1188

1189

1190

1191

1192

1193

1194

1195

1196

1197

1198

1199

1200

1201

1202

1203

1204

1205

1206

1207

1208

1209

1210

1211

1212

1213

1214

1215

1216

Pearson HC, Davis RW (2005) Behavior of territorial male sea otters in Prince William Sound, Alaska. Aquatic Mammals 31: 226-233.

Pellis SM (1984) Some Aspects of Play-Fighting in a Captive Group of Oriental Small-Clawed Otters, Amblonyx cinerea. Z Tierpsychol (Ethology) 65: 77-83.

Pennisi E (2005) How did cooperative behavior evolve. Science 309: 93558.

Perdue BM, Snyder RJ, Maple TL (2013) Cognitive Research in Asian Small-Clawed Otters. Int J Comp Psychol 26: 105-113.

Perinchery A (2008) Conservation genetics of Indian otters and their habitat use in Eravikulam National Park. Ph.D. Thesis Manipal Univ, Manipal, India.

Perinchery A, Jathanna D, Kumar A (2011) Factors determining occupancy and habitat use by Asian small-clawed otters in the Western Ghats, India. J Mammal 92: 796-802.

Perrin MR, D'inzillo Carranza I (2000) Habitat use by spotted-necked otters in the KwaZuluNatal Drakensberg. Afr J Wildl Res 30: 8-14.

Perrin N, Mazalov V (2000) Local competition, inbreeding and the evolution of sex-biased dispersal. Am Nat 155: 116-127.

Pope TR (1990) The reproductive consequences of male cooperation in the red howler monkey, paternity exclusion in multi-male and single-male troops using genetic markers. Behav Ecol Sociobiol 27: 439-446.

Powell RA (1979) Mustelid spacing patterns, variations on a theme by Mustela. Z Tierpsychol 50: 153-165.

Prakash N (2010). Factors influencing the occurrence and habitat use of small- clawed otters (Aonyx cinerea) in the human-modified landscape of Western Ghats, South India. Thesis, Nat. Cent. Biol. Sciences, Tata Institute of Fundamental Research. India.

Prigioni C, Balestrieri A, Remonti L, Gargaro A, Priore G (2006) Diet of the Eurasian otter Lutra lutra. in relation to freshwater habitats and alien fish species in southern Italy. Ethol Ecol Evol 18: 307-320.

Prox, LM, Farine DR (2020) A framework for conceptualizing dimensions of social organization in mammals. Ecology \& Evolution 10: 791-807.

Pusey AE (1987) Sex-biased dispersal and inbreeding avoidance in birds and mammals. TREE 2: 295-299.

Quaglietta L, Fonseca da Silva V, Mira A, Boitani L (2014) Sociospatial organization of a solitary carnivore, the Eurasian otter ( Lutra lutra ). J Mamm 95: 140-150. 10.1644/13-MAMM-A073.1.

Raha A, Hussain SA (2016) Factors affecting habitat selection by three sympatric otter species in the southern Western Ghats, India. Acta Ecol Sin 36:45-49. 10.1016/j.chnaes.2015.12.002.

Ratnayeke S, Tuskan GA, Pelton MR (2002) Genetic relatedness and female spatial organization in a solitary carnivore, the raccoon, Procyon lotor. Mol Ecol 11: 1115-1124. 
Ray J (1997) Comparative ecology of two African forest mongooses, Herpestes naso and Atilax paludinosus. Af J Ecol 35: 237-253.

Reeve HK, Keller L (1995) Partitioning of reproduction in mother-daughter versus sibling associations, a test of optimal skew theory. Am Nat 145: 119-132.

Reiczigel J, Lang Z, Rózsa L, Tóthmérész B (2008) Measures of sociality, two different views of group size. Anim Behav 75: 715-721.

Reid DG, Code TE, Reid ACH, Herrero SM (1994) Food habits of the river otter in a boreal ecosystem. Can J Zool 72: 1306-1313.

Remonti L, Prigioni C, Balestrieri A, Sgrosso S, Priore G (2008) Trophic flexibility of the otter (Lutra lutra) in southern Italy. Mamm Biol 73: 293-302.

Revilla E (2003) Moving beyond the resource dispersion hypothesis. TREE 18: 380.

Revilla E, Palomares F (2002) Spatial organization, group living and ecological correlates in low-density populations of Eurasian badgers, Meles meles. J Anim Ecol 71: 497-512.

Rheingantz ML, Waldemarin HF, Rodrigues L, Multon TP (2011) Seasonal and spatial differences in feeding habits of the Neotropical otter Lontra longicaudis. Carnivora, Mustelidae. in a coastal catchment of southeastern. Brazil Zool 28: 37-44.

Ribas C, Cunha H, Damasceno G, Magnusson W, Solé-Cava A, Mourão G (2015) More than meets the eye: kinship and social organization in giant otters (Pteronura brasiliensis). Behav Ecol Sociobiol 70. 10.1007/s00265-015-2025-7.

Riedman ML, Estes JA (1990) The sea otter (Enhydra lutris): behavior, ecology, and natural history. U.S. Fish and Wild Serv Biol Report 90 (14) : Washington, D.C.

Rock KR, Rock ES, Bowyer RT, Faro JB (1994) Degree of association and use of a helper by coastal river otters, Lutra canadensis, in Prince William Sound, Alaska. Can Field Nat 108: 367-369.

Rosas FCW, Zuanon JAS, Carter SK (1999) Feeding Ecology of the Giant Otter, Pteronura brasiliensis. Biotropica 31: 502-506.

Rowe-Rowe DT, Somers MJ (1998) Diet, foraging behaviour and coexistence of African otters and the water mongoose. Symp Zool Soc Lond 71: 216-227.

Rubenstein DR, Lovette IJ (2007) Temporal environmental variability drives the evolution of cooperative breeding in birds. Curr Biol 17: 1414-1419.

Ruckstuhl KE, Neuhaus P (2000) Sexual segregation in ungulates, a new approach. Behavior 137, 361-377

Sachs JL (2004) The Evolution of Cooperation. Quart Rev Biol 79: 135-160.

Schradin C, Pillay N (2005) Intraspecific variation in the spatial and social organization of the African striped mouse. J Mammal 86: 99-107.

Schröpfer R, Wiegand P, Hogrefe HH (1997) The implications of territoriality for the social system of the European pine marten Martes martes (L. 1758). Z Säugetierk 62: 209-218. 
1254

1255

1256

1257

1258

1259

1260

1261

1262

1263

1264

1265

1266

1267

1268

1269

1270

1271

1272

1273

1274

1275

1276

1277

1278

1279

1280

1281

1282

1283

1284

1285

1286

1287

1288

1289

1290

1291

Sepúlveda MA, Bartheld JL, Monsalve R, Gómez V, Medina-Vogel G (2007) Habitat use and spatial behaviour of the endangered Southern river otter Lontra provocax in riparian habitats of Chile, conservation implications. Biol Conserv 140: 329-338.

Sepúlveda MA, Bartheld JL, Meynard C, Astorga C, Benavides M, Parra D, Medina-Vogel G (2009) Landscape features and crustacean prey as predictors of the Southern river otter (Lontra provocax) distribution in Chile. Anim Conserv 12: 522-530.

Shannon JS (1991) Social organization and behavioral ontogeny of otters Lutra Canadensis in a coastal habitat in northern California. Bull Otter Specialist Group 4: 8-13.

Schmelz M, Duguid S, Bohn M, Volter C (2017) Cooperative problem solving in giant otters (Pteronura brasiliensis) and Asian small-clawed otters (Aonyx cinerea). Anim Cogn 20:1107. https://doi.org/10.1007/s10071-017-1126-2

Sherman PW (1977) Nepotism and the evolution of alarm calls. Science 197: 1246-1253.

Shorey L, Piertney S, Stone J, Hoglund J (2000) Fine scale genetic structuring on Manacus manacus leks. Nature 408: 352-353.

Silk JB (2007) The adaptive value of sociality in mammalian groups. Phil. Trans. R. Soc. B-Biol. Sci. 362: 539-559.

Sivasothi N (1996) The Small-clawed otter, Amblonyx cinereus (Illiger, 1815) (Carnivora. Mustelidae. Lutrinae), the second resident wild carnivore in Singapore. Report of a family group on Pulau Tekong Besar and of the fate of wildlife there. The Pangolin, 7: 23-31.

Sivasothi N, Nor BHM (1994) A review of otters (Carnivora. Mustelidae. Lutrinae) in Malaysia and Singapore. Hydrobiologia 285: 151-170.

Sjöåsen T (1997) Movements and establishment of reintroduced European otters Lutra lutra. J App Ecol 34: 1070-1080.

Smith JE, Kolowski JM, Graham KE, Dawes SE, Holekamp KE (2008) Social and ecological determinants of fission-fusion dynamics in the spotted hyaena. Anim Behav 76: 619-636.

Smith JE, Swanson EM, Reed D, Holekamp KE (2012) Evolution of Cooperation among Mammalian Carnivores and Its Relevance to Hominin Evolution. Curr Anthropol 53: 436-452.

Snowdon CT, Cronin KA (2007) Cooperative breeders do cooperate. Behav Proc 76: 138-141.

Somers MJ (2000) Foraging behaviour of Cape clawless otters (Aonyx capensis) in a marine habitat. J Zool Lond 252: 473-480.

Somers MJ, Nel JAJ (2003) Diet in relation to prey of Cape clawless otters in two rivers in the Western Cape Province, South Africa. Afr J Ecol 38: 317-326.

Spong G, Stone J, Creel S, Bjorklund M (2002) Genetic structure of lions Panthera leo L. in the Selous Game Reserve, implications for the evolution of sociality. J Evol Biol 15: 945-953.

Stiver KA, Fitzpatrick J, Desjardins JK, Balshine S (2006) Sex differences in rates of territory joining and inheritance in a cooperatively breeding cichlid fish. Anim Behav 71: 449-456.

Townsend SW, Zöttl M, Manser MB (2011) All clear? Meerkats attend to contextual information in close calls to coordinate vigilance. Behav Ecol Sociobiol 65:1927-1934 
Trivers RL (1971) The evolution of reciprocal altruism. Q Rev Biol 46: 35-57.

Tyack P (1986) Population biology, social behavior and communication in whales and dolphins. TREE 1:144-150.

Valqui $\mathrm{J}(2011)$ The marine otter Lontra felina (Molina, 1782). A review of its present status and implications for future conservation. Mammal Biol (Z Säugetierk) 77: 75-83.

Vehrencamp SL (1983) Optimal degree of skew in cooperative societies. Am Zool 23: 327-335.

Verdolin JL (2009) Gunnison's prairie dog Cynomys gunnisoni testing the resource dispersion hypothesis. Behav Ecol Sociobiol 63: 789-799.

Véron G, Colyn M, Dunham A, Taylor P, Gaubert P (2004) Molecular systematics and origin of sociality in mongooses Herpestidae Carnivora. Mol Phyl Evol 30: 582-598.

Villegas MJ, Aron A, Ebensperger LA (2007) The influence of wave exposure on the foraging activity of marine otter, Lontra felina (Molina, 1782) (Carnivora Mustelidae) in northern Chile. $J$ Ethol 25: 281-286.

Wagner AP, Creel S, Frank LG, Kalinowski ST (2007) Patterns of relatedness and parentage in an asocial, polyandrous striped hyena population. Mol Ecol 16: 4356-4369.

Waser PM, Keane B, Creel SR, Elliot LG, Minchella DJ (1994) Possible male coalitions in a solitary mongoose. Anim Behav 47: 289-294.

Wasser SK, Barash DP (1983) Reproductive suppression among female mammals, implications for biomedicine and sexual selection theory. Quart Rev Biol 58: 513-538.

Weber JM (1990) Seasonal exploitation of amphibians by otters Lutra lutra in north-east Scotland. J Zool 220: 641-651.

West SA, Griffin AS, Gardner A (2007) Evolutionary explanations for cooperation. Curr Biol 17: R661-R672

West SA, Pen I, Griffin AS (2002) Cooperation and competition between relatives. Science 296: 72-75.

Wickler W, Seibt U (1993) Pedogenetic sociogenesis via the 'siblingroute' and consequences for Stegodyphus spiders. Ethology 95: 1-18.

Williams DA, Rabenold KN (2005) Male-biased dispersal, female philopatry and routes to fitness in a social corvid. J Anim Ecol 74: 150-159.

Wilson DS (1990) Weak Altruism, Strong Group Selection. Oikos 59: 135-148.

Wrangham RW, Rubenstein DI (1986) Social evolution in birds and mammals. In: Rubenstein DI, Wrangham RW (eds) Ecological aspects of social evolution in birds and mammals. Princeton Univ. Press, Princeton, New Jersey: pp 452-470.

Wright J, Berg H, De Kort SR, Khazin V, Maklakov AA (2001) Cooperative sentinel behaviour in the Arabian babbler. Anim Behav 62: 973-979.

Yamagiwa J, Kahekwa J, Kanyunyi Basabose A (2003) Intra-specific variation in social organization of gorillas. implications for their social evolution. Primates 44: 359-369. 
1329 Yamaguchi N, Sarno RJ, Jhonson WE, O'Brien S, Macdonald DW (2004) Multiple Paternity and 1330 Reproductive Tactics of Free-Ranging American Minks, Mustela vison. J. Mammal., 85, 3, 1331 432-439, https://doi.org/10.1644/1383939

1332 Ylönen H, Brown JS (2007) Fear and the Foraging, Breeding and Sociality in Rodents. In: Wolff 1333 JO, Sherman PW (eds) Rodent Societies. Univ Chicago Press, Chicago: pp. 328-341.

1334 Young AJ, Carlson AA, Monfort SL, Russell AF, Bennett NC, Clutton-Brock TH (2006) Stress 1335 and the suppression of subordinate reproduction in cooperatively breeding meerkats. PNAS 1336 103: 12005-12010.

1337 
Table I. Social traits of 14 otter species. Family structure refers to pairs, social structure refers to extended family and highly social structure refers to groups including helpers.

\begin{tabular}{|c|c|c|c|c|}
\hline Species & & Habitat & Lifestyle & $\begin{array}{l}\text { Parental } \\
\text { investm } \\
\text { ent }\end{array}$ \\
\hline $\begin{array}{l}\text { Congo clawless } \\
\text { otter }\end{array}$ & $\begin{array}{l}\text { Aonyx } \\
\text { congicus }\end{array}$ & $\begin{array}{c}\text { fresh rivers, ponds, } \\
\text { marshes, lakes }\end{array}$ & solitary & female \\
\hline $\begin{array}{l}\text { Neotropical river } \\
\text { otter }\end{array}$ & $\begin{array}{l}\text { Lontra } \\
\text { longicaudis }\end{array}$ & $\begin{array}{l}\text { rivers, lakes, small } \\
\text { streamlets, } \\
\text { coast, lagoons }\end{array}$ & solitary & female \\
\hline Hairy-nosed otter & $\begin{array}{l}\text { Lutra } \\
\text { sumatrana }\end{array}$ & $\begin{array}{l}\text { fast flowing rivers, } \\
\text { peat swamp, } \\
\text { streams, } \\
\text { mountain rivers }\end{array}$ & solitary & female \\
\hline $\begin{array}{l}\text { Japanese otter } \\
\text { (Extinct) }\end{array}$ & Lutra nippon & $\begin{array}{l}\text { fresh rivers, ponds, } \\
\text { marshes }\end{array}$ & solitary & female \\
\hline $\begin{array}{l}\text { Southern river } \\
\text { otter }\end{array}$ & $\begin{array}{l}\text { Lontra } \\
\text { provocax }\end{array}$ & $\begin{array}{l}\text { fresh rivers, ponds, } \\
\text { marshes }\end{array}$ & solitary & female \\
\hline $\begin{array}{l}\text { Spotted necked } \\
\text { otter }\end{array}$ & $\begin{array}{l}\text { Lutra } \\
\text { maculicollis }\end{array}$ & lakes, large rivers & $\begin{array}{l}\text { solitary or family } \\
\text { group }\end{array}$ & female \\
\hline Marine otter & Lontra felina & $\begin{array}{l}\text { rocky coasts and } \\
\text { seashores }\end{array}$ & $\begin{array}{l}\text { family group, but } \\
\text { sometimes } \\
\text { solitary }\end{array}$ & pair \\
\hline $\begin{array}{l}\text { Smooth coated } \\
\text { otter }\end{array}$ & $\begin{array}{l}\text { Lutrogale } \\
\text { perspicillata }\end{array}$ & $\begin{array}{l}\text { large forested } \\
\text { rivers, swamps }\end{array}$ & $\begin{array}{l}\text { solitary or family } \\
\text { group }\end{array}$ & female \\
\hline European otter & Lutra lutra & $\begin{array}{l}\text { fresh water } \\
\text { ecosystems and } \\
\text { rocky coasts }\end{array}$ & $\begin{array}{l}\text { mostly solitary, } \\
\text { sometimes } \\
\text { social }\end{array}$ & female \\
\hline $\begin{array}{l}\text { Cape clawless } \\
\text { otter }\end{array}$ & $\begin{array}{l}\text { Aonyx } \\
\text { capensis }\end{array}$ & $\begin{array}{l}\text { marshes, rocky } \\
\text { coasts and } \\
\text { seashores, } \\
\text { mangrove }\end{array}$ & $\begin{array}{rr}\text { solitary, } & \text { family } \\
\text { group } & \text { or } \\
\text { social } & \end{array}$ & pair \\
\hline
\end{tabular}




\begin{tabular}{|c|c|c|c|c|}
\hline Sea otter & Enhydra lutris & oceanic kelp forests & social & $\begin{array}{c}\text { female or } \\
\text { pair }\end{array}$ \\
\hline Giant otter & $\begin{array}{l}\text { Pteronura } \\
\text { brasiliensis }\end{array}$ & $\begin{array}{l}\text { Large low rivers, } \\
\text { flooded rain } \\
\text { forest, } \\
\text { mangroves }\end{array}$ & highly social & helpers \\
\hline $\begin{array}{l}\text { North American } \\
\text { river otter }\end{array}$ & $\begin{array}{l}\text { Lontra } \\
\quad \text { canadensis }\end{array}$ & $\begin{array}{l}\text { fresh rivers, low } \\
\text { rivers, ponds, } \\
\text { lakes, marshes, } \\
\text { rocky coasts }\end{array}$ & $\begin{array}{l}\text { solitary, family } \\
\text { group or } \\
\text { highly social }\end{array}$ & helpers \\
\hline $\begin{array}{c}\text { Oriental small- } \\
\text { clawed otter }\end{array}$ & Aonyx cinerea & $\begin{array}{l}\text { large forested } \\
\text { rivers, swamps, } \\
\text { mangroves }\end{array}$ & $\begin{array}{c}\text { family group or } \\
\text { highly social }\end{array}$ & helpers \\
\hline
\end{tabular}




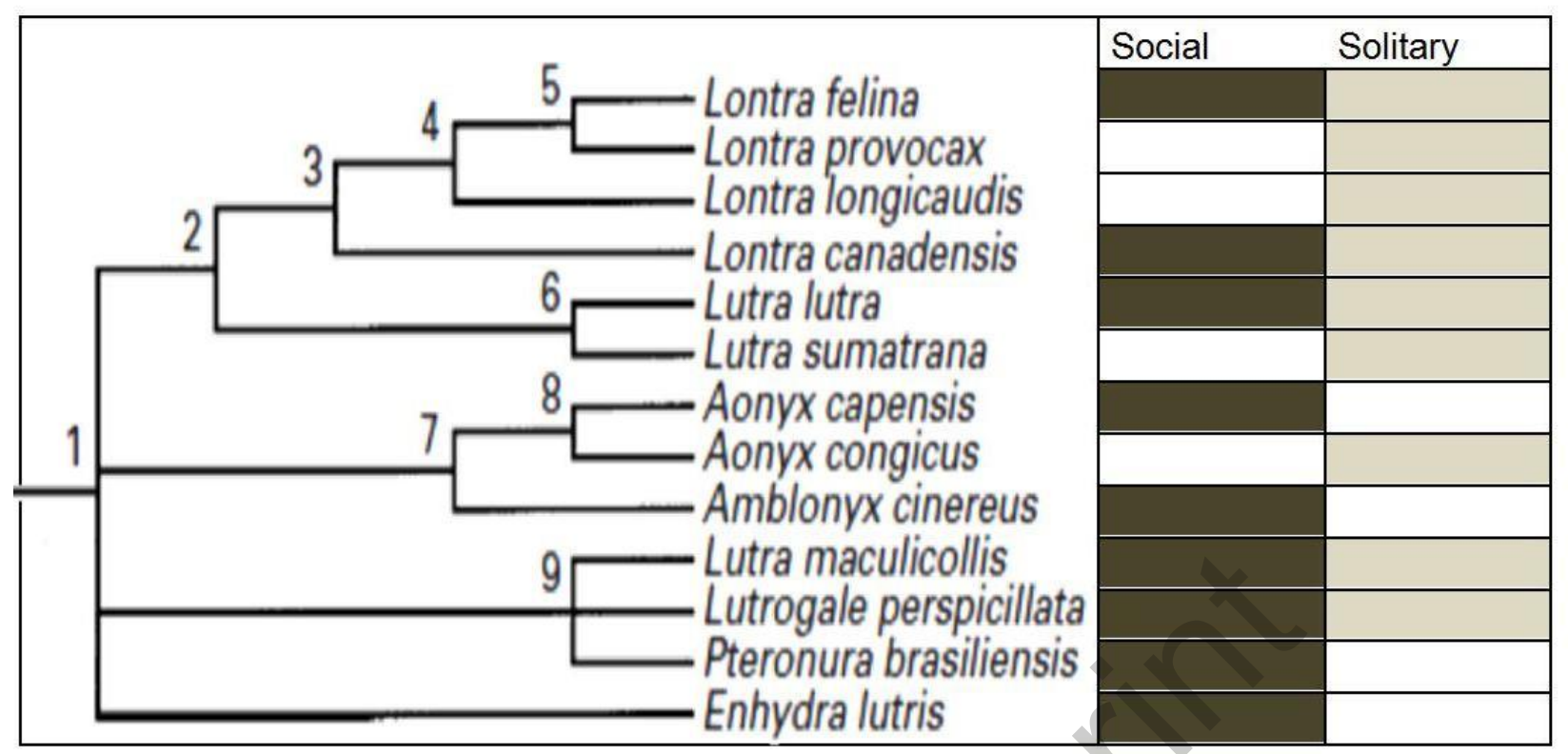

1345

1346

1347

1348

1349

1350

1351

1352

1353

1354

1355

1356

Fig. 1. Phylogenetic relationships evaluated by a super-tree construction (maximum parsimony, maximum likelihood and Bayesian inference methods, from BinindaEdmonds et al. 1999; Koepfli et al. 1998 and Koepfli et al. 2008) related to social life characteristics for 13 otter species: marine otter (Lontra felina), southern river otter (Lontra provocax), neotropical river otter (Lontra longicaudis), North American otter (Lontra canadensis), European otter (Lutra lutra), hairy-nosed otter (Lutra sumatrana), African clawless otter (Aonyx capensis), Congo clawless otter (Aonyx congicus), small-clawed otter (Amblonyx/Aonyx cinerea), spotted-necked otter (Lutra maculicollis), smooth-coated otter (Lutreogale perspicillata), giant otter (Pteronura brasiliensis) and sea otter (Enhydra lutris). (Nodes 1-9 are numbered with bootstrap and posterior probabilities). 


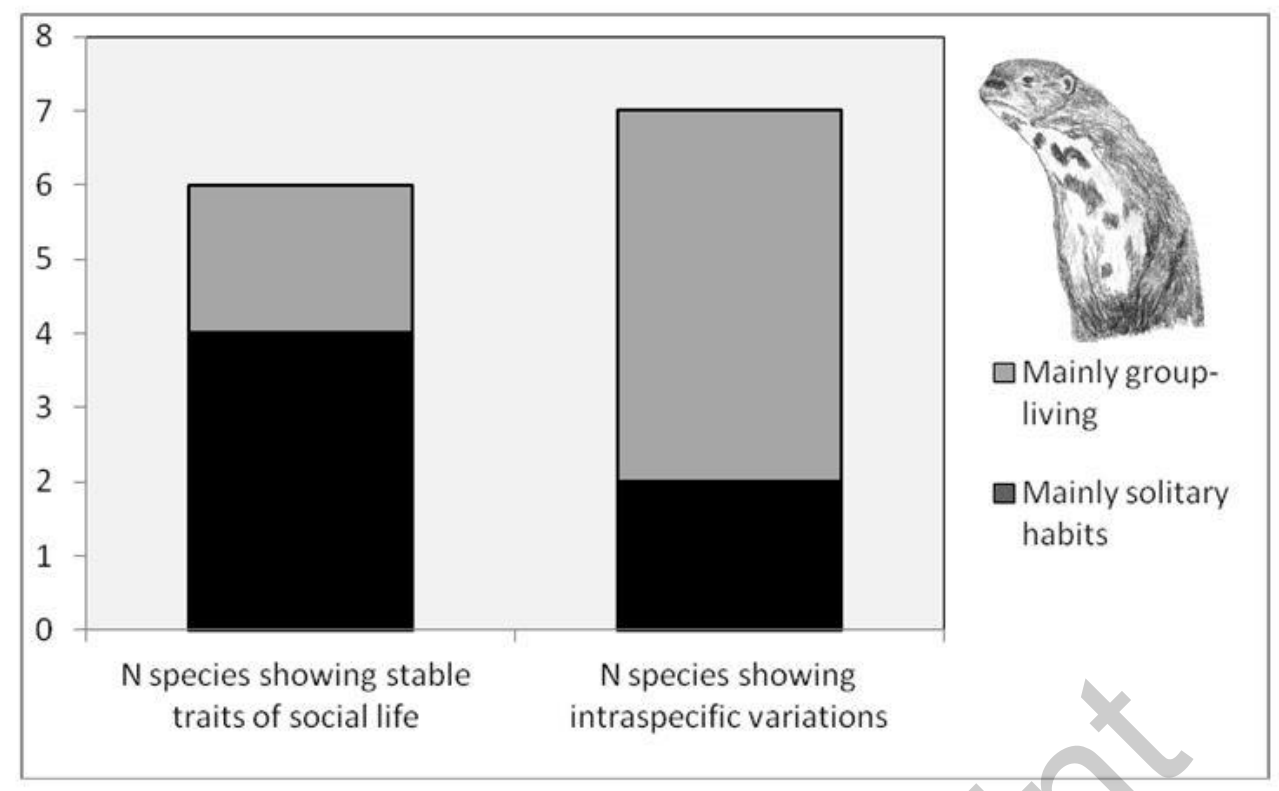

1358 Fig. 2. Intraspecific variations of otters' social structures. European otters (Lutra lutra), spotted necked otters (Lutra maculicollis), smooth-coated otters (Lutrogale perspicillata), North American otters (Lontra Canadensis), marine otters (Lontra feline), small-clawed otters (Aonyx cinereus) and African clawless otters (Aonyx capensis) (54\% of the studied species) present intraspecific variations whereas Congo clawless otters (Aonyx congicus), giant otters (Pteronura brasiliensis), hairynosed otters (Lutra sumatrana), neotropical river otters (Lontra longicaudis), sea otters (Enhydra lutris and, southern river otters (Lontra provocax) (46\%) present stable social organizations. 


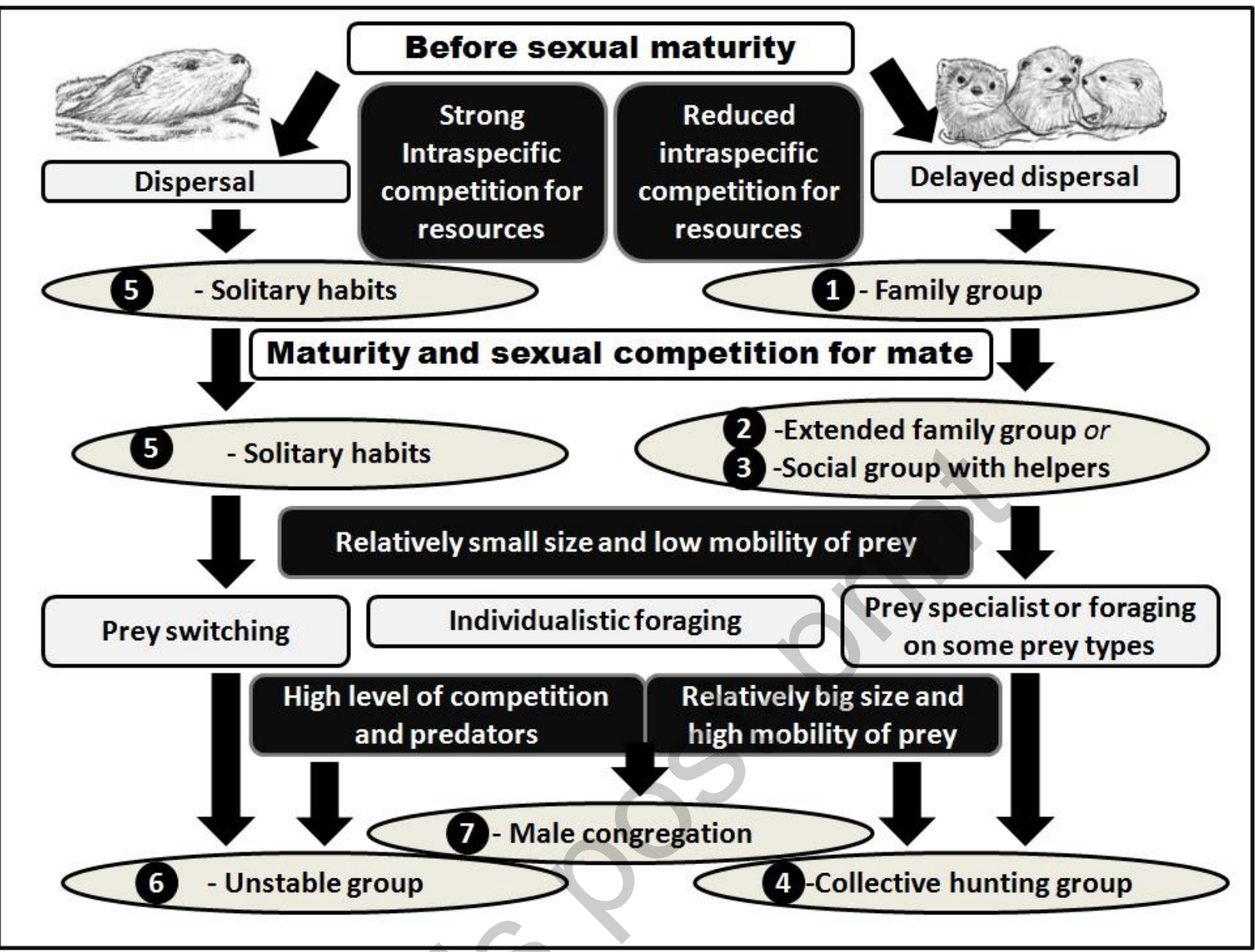

1371 Fig. 3. Schematic representation of the socio-ecological predictions for otters' social 1372 organization (SEB covariance model). White text on black: ecological factors 1373 influencing social decisions; grey background: life style. Black circles: social life 1374 types: 1) family group (offspring disperse when they reach sexual maturity); 2) 1375 extended family group, often with an alpha dominant pair (several generations 1376 cohabit); 3) social group with helpers, generally with an alpha dominant pair; 4) 1377 collective hunting group; 5) solitary life-style (offspring disperse soon after being 1378 weaned); 6) mixed-sex unstable group and 7) male social congregations. 


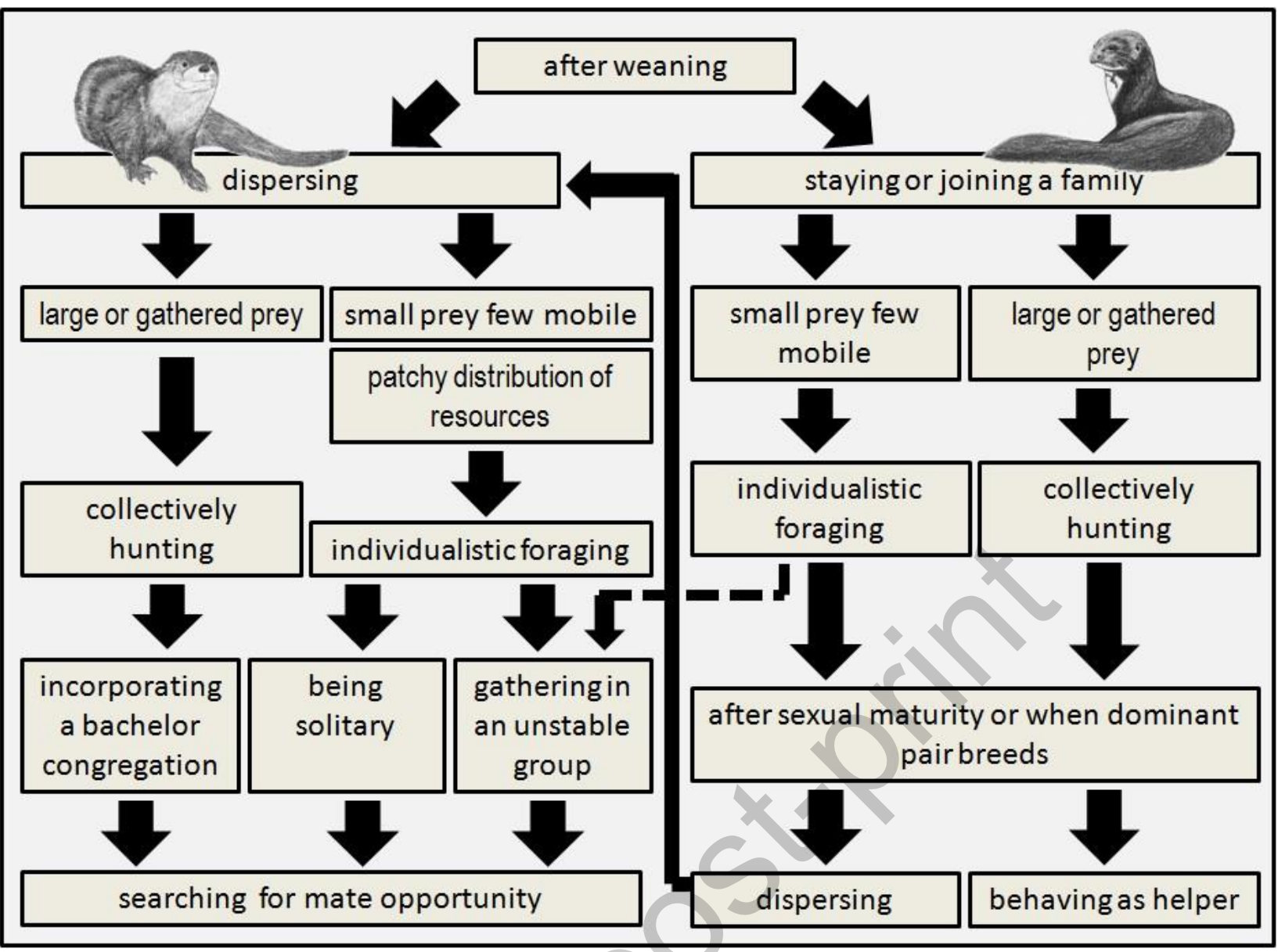

Fig. 4. Sequence of individual step-by-step decisions following sexual, ecological and behavioural covariance in otter species in which each step builds a more or less temporary social organization. Individual otters have to make a number of decisions after weaning: to disperse, to forage solitarily, to remain solitary or to join opportunistically an unstable mixed-sex group or a bachelor group. If it remains in its family group, it can forage either individualistically or collectively according to prey type; sometimes, a family group can join an unstable group temporarily. When the alpha pair breeds, offspring may disperse as in the first option or stay and behave as a subordinate helper, if it is tolerated by the dominant. 